\title{
The Universal Arrow of Time
}

\author{
Oleg Kupervasser ${ }^{1 *}$ Hrvoje Nikolić ${ }^{2 \dagger}$, Vinko Zlatić ${ }^{2 \ddagger}$ \\ ${ }^{1}$ Scientific Research Computer Center, Moscow State University, Moscow, Russia \\ 2 Theoretical Physics Division, Rudjer Bošković Institute, \\ P.O.B. 180, HR-10002 Zagreb, Croatia
}

October 22, 2018

\begin{abstract}
Statistical physics cannot explain why a thermodynamic arrow of time exists, unless one postulates very special and unnatural initial conditions. Yet, we argue that statistical physics can explain why the thermodynamic arrow of time is universal, i.e., why the arrow points in the same direction everywhere. Namely, if two subsystems have opposite arrow-directions at a particular time, the interaction between them makes the configuration statistically unstable and causes a decay towards a system with a universal direction of the arrow of time. We present general qualitative arguments for that claim and support them by a detailed analysis of a toy model based on the baker's map.
\end{abstract}

PACS: 05.20.-y, 05.45.-a

Keywords: time arrow, entropy increase, baker's map

\section{Introduction}

The origin of the arrow of time is one of the greatest unsolved puzzles in physics [1, 2, 3, 4, 5]. It is well established that most arrows of time can be reduced to the thermodynamic arrow, but the origin of the thermodynamic arrow of time remains a mystery. Namely, the existence of the thermodynamic arrow of time means that the system is not in the state with the highest possible entropy. But this means that the system is not in the highest-probable state, which lacks any statistical explanation. The fact that entropy increases with time means that the system was in an even less probable state in the past, which makes the problem even harder. Of course, the phenomenological fact that entropy increases with time can be described by assuming that the universe was in a state with a

\footnotetext{
*olegkup@yahoo.com

†hrvoje@thphys.irb.hr

‡Vinko.Zlatic@irb.hr
} 
very low entropy at the beginning, but one cannot explain why the universe started with such a very special and unnatural initial condition in the first place.

Recently, Maccone [6] argued that the problem of the origin of the arrow of time can be solved by quantum mechanics. He has shown that in quantum mechanics all phenomena which leave a trail behind (and hence can be studied by physics) are those the entropy of which increases. (The observer's memory erasing argument and the corresponding thought experiments discussed in [6] has also been used previously for a resolution of entropy increase and the quantum wave-packet reduction paradoxes [7, 8, 9].) From this he argued that the second law of thermodynamics is reduced to a mere tautology, suggesting that it solves the problem of the arrow of time in physics. However, several weaknesses on specific arguments used in [6] have been reported [10, 11, 12]. As a response to one of these objections, in a later publication [13] Maccone himself realized that his approach does not completely solve the origin of the arrow of time because the quantum mechanism he studied also requires highly improbable initial conditions which cannot be explained.

Yet, as Maccone argued in [13], we believe that some ideas presented in [6] and [13] do help to better understand the puzzle of the arrow of time. The purpose of this paper is to further develop, refine, clarify, and extend some of the ideas which were presented in [6, 13, 11], and also in a somewhat different context in [8, 9, 14, 15, 16, 17, 18. In particular, unlike Maccone in [6, 13], we argue that quantum mechanics is not essential at all. Indeed, in this paper we consider only classical statistical mechanics.

The idea is the following. Even though statistical physics cannot explain why a thermodynamic arrow of time exists, we argue that at least it can explain why the thermodynamic arrow of time is universal, i.e., why the arrow points in the same direction everywhere. Namely, if two subsystems have opposite arrow-directions initially, we argue that the interaction between them makes the configuration statistically unstable and causes a decay towards a system with a universal direction of the arrow of time. This, of course, does not completely resolve the problem of the origin of the arrow of time. Yet, at least, we believe that this alleviates the problem.

The paper is organized as follows. In the next section we present our main ideas in an intuitive non-technical form. After that, in Sec. 3 we study the statistical properties of the baker's map (some basic properties of which are presented in the Appendix), which serves as a toy model for studying generic features of reversible chaotic Hamiltonian systems. As a byproduct, in that section we also clarify the differences between various notions of "entropy". Then, in Sec. 4 we study the effects of weak interactions between subsystems which, without interactions, evolve according to the baker's map. In particular, we explain how weak interactions destroy the opposite time arrows of the subsystems, by making them much more improbable than without interactions. Finally, in Sec. 5 we present a qualitative discussion of our results, including the consistency with strongly-interacting systems in which the entropy of a subsystem may decrease with time.

\section{Main ideas}

To avoid ambiguity in further discussions, let us first explain our basic concepts and terminology used in the rest of the paper. For that purpose it is useful to visualize time 
as a continuous 1-dimensional line. The line is coordinatized by a continuous parameter $t$. Such a coordinatization necessarily involves an orientation of the time-line with a direction pointing from a smaller to a larger value of $t$. We can use this orientation to define the notions such as "before" and "after", "past" and "future", or "initial" and "final". In this paper, unless stated otherwise, by these notions we mean the notions defined with respect to this coordinate time $t$. However, we stress that such an orientation of coordinate time is merely a matter of choice and does not have any physical content. In particular, such an orientation by itself does not involve any arrow of time. Instead, by an arrow of time we mean a physical phenomenon, like a phenomenon that entropy increases or decreases with time $t$. When the arrow of time points in the same direction everywhere along the time-line, then the coordinate time can be defined such that the orientation of $t$ coincides with the arrow of time. That allows us to abuse the language at some places by arguing that entropy "increases" rather than "decreases" with time, but one should have in mind that the difference between increase and decrease with time is really a matter of definition. In general, the arrow of time and orientation of $t$ are logically independent concepts.

Now let us discuss the thermodynamic arrow of time. A priori, the probability of having a thermodynamic arrow of time is very low. However, our idea is to think in terms of conditional probabilities. Given that a thermodynamic arrow exists, what can we, by statistical arguments, infer from that?

To answer that question, let us start from the laws of an underlying microscopic theory. We assume that dynamics of microscopic degrees of freedom is described by a set of second-order differential equations (with derivatives with respect to time) which are invariant under the time inversion $t \rightarrow-t$. Thus, both directions of time have an a priori equal roles. To specify a unique solution of the dynamical equations of motion, one also needs to choose some "initial" time $t_{0}$ on which initial conditions are to be specified. (The "initial" time does not necessarily need to be the earliest time at which the universe came into the existence. For any $t_{0}$ at which the initial conditions are specified, the dynamical equations of motion uniquely determine the state of the universe for both $t>t_{0}$ and $t<t_{0}$.) It is a purely conventional particular instant on time, which may be even in the "future". Indeed, in this paper we adopt the "block-universe" picture of the world (see, e.g., [4, 19, 20, 21] and references therein), according to which time does not "flow". Instead, the universe is a "static" object extended in 4 spacetime dimensions.

Of course, the a priori probability of small entropy at $t_{0}$ is very low. But given that entropy at $t_{0}$ is small, what is the conditional probability that there is a thermodynamic arrow of time? It is, of course, very high. However, given that entropy at $t_{0}$ is low, the most probable option is that entropy increases in both directions with a minimum at $t_{0}$. (We present an example in Fig. 4 of Sec. 4.4.) Clearly, in such a case the system is symmetric under the inversion $\left(t-t_{0}\right) \rightarrow-\left(t-t_{0}\right)$. The thermodynamic arrow of time for $t>t_{0}$ has the opposite direction than that for $t<t_{0}$. Thus, even though neither direction of time has a preferred physical role globally, a thermodynamic arrow of time can still be assigned locally for various times $t \neq t_{0}$.

On the other hand, at times at which we make measurements in practice, the entropy is indeed low, but entropy does not increase in both directions. Instead, it increases in only one direction. (In other words, a typical time $t_{0}$ at which we make a measurement is not a time at which entropy attains a minimum, which is why nature does not appear time-inversion symmetric to us.) This is because, on a typical $t_{0}$, not only the "initial" 
entropy is specified, but a particular direction of the entropy increase is specified as well. At the microscopic level, this is related to the fact that on $t_{0}$ one does not only need to specify the initial particle positions, but also their initial velocities.

And now comes the central question of this section. Given that at $t_{0}$ the entropy is low, why entropy at $t_{0}$ increases in the same (say, positive) direction everywhere? Isn't it more probable that the direction of entropy-increase varies from point to point at $t_{0}$ ? If so, then why don't we observe it? In other words, why the arrow of time is universal, having the same direction everywhere for a given $t_{0}$ ? We refer to this problem as the problem of universality of the arrow of time.

In this paper we argue that this problem can be solved by statistical physics. In short, our solution is as follows. If we ignore the interactions between different degrees of freedom, then, given that at $t_{0}$ the entropy is low, the most probable option is, indeed, that the direction of the arrow of time varies from point to point. On the other hand, if different degrees of freedom interact with each other, then it is no longer the most probable option. Instead, even if the direction of the arrow of time varies from point to point at $t_{0}$, the interaction provides a natural mechanism that aligns all time arrows to the same direction.

To illustrate the arrow-of-time dilemma, the thought experiments of Loschmidt (time reversal paradox) and Poincare (recurrence theorem) are also often used. The corresponding paradoxes in classical mechanics are resolved as follows. Classical mechanics allows, at least in principle, to exclude any effect of the observer on the observed system. However, most realistic systems are chaotic, so a weak perturbation may lead to an exponential divergence of trajectories. In addition, there is also a non-negligible interaction. As a simple example, consider a gas expanding from a small region of space into a large volume. In this entropy-increasing process, the time evolution of macroscopic parameters is stable against small external perturbations. On the other hand, if all the velocities are reversed, then the gas will end up in the initial small volume, but only in the absence of any perturbations. The latter entropy-decreasing process is clearly unstable and a small external perturbation would trigger a continuous entropy growth. Thus the entropy increasing processes are stable, but the decreasing ones are not. A natural consequence is that the time arrows (the directions of which are defined by the entropy growth) of both the observer and the observed system are aligned to the same direction, because of the inevitable non-negligible interaction between them. They can return back to the initial state only together (as a whole system) in both Loschmidt and Poincare paradoxes. so the observer's memory gets erased in the end. In particular, the observer's memory gets erased in the end, because we assume that everything, including the observer's brain, is reversed to the state identical to an old state describing the system before the memory has been created. During this process the time arrow of the observer points in the backward direction, which has two consequences. First, an entropy growth is observed in the whole system as well as in its two parts, despite the fact that entropy decreases with coordinate time. Second, the memory of the observer is erased not only at the end but also close to that point, because the observer does not remember his "past" (defined with respect to the coordinate time), but remembers his "future". Of course, the observer himself cannot know that the arrow of time has reversed its direction, because he can only observe the physical "past" and "future" defined not with respect to the coordinate time, but with respect to the direction in which entropy increases. 
Indeed, it may seem quite plausible that interaction will align all time arrows to the same direction. But the problem is - which direction? The forward direction, or the backward one? How can any particular direction be preferred, when both directions are a priori equally probable? Is the common direction chosen in an effectively random manner, such that it cannot be efficiently predicted? Or if there are two subsystems with opposite directions of time at $t_{0}$, will the "stronger" subsystem (i.e., the one with a larger number of degrees of freedom) win, such that the joint system will take the direction of the "stronger" subsystem as their common direction?

The answer is as follows: It is all about conditional probabilities. One cannot question the facts which are already known, irrespective of whether these facts are in "future" or "past". The probabilistic reasoning is to be applied to only those facts which are not known yet. So, let us assume that the entropy is low at $t_{0}$ and that we have two subsystems with opposite time directions at $t_{0}$. Let us also assume that the subsystems do not come into a mutual interaction before $t_{1}$ (where $t_{1}>t_{0}$ ), after which they interact with each other. Given all that, we know that, for $t_{0}<t \leq t_{1}$, entropy increases with time for one subsystem and decreases with time for another subsystem. But what happens for $t>t_{1}$ ? Due to the interaction, the two subsystems will have the same direction of the arrow of time for $t>t_{1}$. But which direction? The probabilistic answer is: The direction which is more probable, given that we know what we already know. But we already know the situation for $t<t_{1}$ (or more precisely, for $t_{0}<t \leq t_{1}$ ), so our probabilistic reasoning can only be applied to $t>t_{1}$. It is this asymmetry in knowledge that makes two directions of time different. (Of course, the interaction is also asymmetric, in the sense that interaction exists for $t>t_{1}$, but not for $t_{0}<t \leq t_{1}$.) Thus, the probabilistic reasoning implies that entropy will increase in the positive time direction for $t>t_{1}$. Alternatively, if there was no such asymmetry in knowledge, we could not efficiently predict the direction of the arrow of time, so the joint direction would be chosen in an effectively random manner.

Note also that the mechanism above does not depend much on relative sizes of the two subsystems. In particular, if they are of an equal size, i.e., half of the system has the time arrow oriented opposite to the other half for $t_{0}<t \leq t_{1}$, the common time arrow for $t>t_{1}$ will still be determined by the aforementioned asymmetry in knowledge.

Further note that the qualitative probabilistic arguments above refer to expectations on typical systems, not necessarily on all possible systems. Indeed, there are interesting physical systems, such as those involving the spin-echo effect, in which a subsystem may have the arrow of time opposite to that of its environment. The point is that such systems are exceptions, rather than a rule. Thus, our qualitative probabilistic arguments against such systems are still justified, provided that one does not misinterpret them as strict laws without exceptions.

In fact, it is not difficult to understand qualitatively why exceptions such as the spinecho effect exist. First, it is a system with a relatively small number of degrees of freedom, which makes the statistical arguments less accurate and fluctuations more likely. Second, the interaction of this system with the environment is so weak so that the mechanism of entropy alignment takes more time than in most other systems. Indeed, even the spinecho system will eventually, after a sufficient time, align its time-direction with that of its environment.

To emphasize that no direction of time is a priori preferred, let us also briefly discuss a situation inverse to the above. For that purpose, now let us assume that interaction 
exists only for $t<t_{-1}$, where $t_{-1}<t_{0}$. By completely analogous reasoning, now we can conclude that the entropy will increase in the negative time direction for $t<t_{-1}$.

A fully symmetric variant is also possible by assuming that the interaction exists for both $t>t_{1}$ and $t<t_{-1}$ (but not for $t_{-1} \leq t \leq t_{1}$ ). In this case, the entropy will increase in the positive time direction for $t>t_{1}$ and in the negative time direction for $t<t_{-1}$. In other words, similarly to the case in Fig. 4 of Sec. 4.4, the entropy will increase in both directions, but for different times.

One additional note on initial conditions is in order. Even when two subsystems have the opposite directions of the thermodynamic arrow of time, we choose the initial conditions for both of them to be at the same time $t_{0}$, say in the past. Indeed, the choice that $t_{0}$ is in the past is a natural choice for the subsystem in which entropy increases with time. However, this choice is not so natural for the other subsystem in which entropy decreases with time; for that subsystem it would be more natural to choose the "initial" condition in the future. Or more generally, one might like to study many subsystems, each with initial conditions at another time. We stress that in this paper we do not study such more general initial conditions because, when interactions between the subsystems are present, initial conditions at different times for different subsystems cannot be chosen arbitrarily. Namely, for some choices of such initial conditions at different times, a selfconsistent solution of the dynamical equations of motion may not even exist. And even when a solution exists, in general it is not known how to prove the existence or how to find a solution numerically.

Now we can understand why the arrow of time appears to be universal. If there is a subsystem which has an arrow of time opposite to the time-arrow that we are used to, then this subsystem is either observed or not observed by us. If it is not observed, then it does not violate the fact that the arrow of time appears universal to us. If it is observed then it interacts with us, which implies that it cannot have the opposite arrow of time for a long time. In each case, the effect is that all what we observe must have the same direction of the arrow of time (except, perhaps, during a very short time interval). This is similar to the reasoning in [6], with an important difference that our reasoning does not rest on quantum mechanics.

In the remaining sections we support these intuitive ideas by a more quantitative analysis.

\section{$3 \quad$ Statistical mechanics of the baker's map}

The baker's map (for more details see Appendix A) maps any point of the unit square to another point of the same square. We study a collection of $N \gg 1$ such points (called "particles") that move under the baker's map. This serves as a toy model for a "gas" that shares all typical properties of classical Hamiltonian reversible deterministic chaotic systems. Indeed, due to its simplicity, the baker's map is widely used for such purposes [22, 23, 24, 25]. 


\subsection{Macroscopic entropy and ensemble entropy}

To define a convenient set of macroscopic variables, we divide the unit square into 4 equal subsquares. Then the 4 variables $N_{1}, N_{2}, N_{3}, N_{4}$, denoting the number of "particles" in the corresponding subsquares, are defined to be the macroscopic variables for our system. (There are, of course, many other convenient ways to define macroscopic variables, but general statistical conclusions are not expected to depend on this choice.) The macroscopic entropy $S_{\mathrm{m}}$ of a given macrostate is defined by the number of different microstates corresponding to that macrostate, as

$$
S_{\mathrm{m}}=-N \sum_{k=1}^{4} \frac{N_{k}}{N} \log \left(\frac{N_{k}}{N}\right)=-\sum_{k=1}^{4} N_{k} \log \left(\frac{N_{k}}{N}\right) .
$$

This entropy is maximal when the distribution of particles is uniform, in which case $S_{\mathrm{m}}$ is $S_{\mathrm{m}}^{\max }=N \log 4$. Similarly, the entropy is minimal when all particles are in the same subsquare, in which case $S_{\mathrm{m}}=0$.

Let $(x, y)$ denote the coordinates of a point on the unit square. In physical language, it corresponds to the particle position in the 2-dimensional phase space. For $N$ particles, we consider a statistical ensemble with a probability density $\rho\left(x_{1}, y_{1} ; \ldots ; x_{N}, y_{N} ; t\right)$ on the $2 N$ dimensional phase space. Here $t$ is the evolution parameter, which takes discrete values $t=0,1,2, \ldots$ for the baker's map. Then the ensemble entropy is defined as

$$
S_{\mathrm{e}}=-\int \rho\left(x_{1}, y_{1} ; \ldots ; x_{N}, y_{N} ; t\right) \log \rho\left(x_{1}, y_{1} ; \ldots ; x_{N}, y_{N} ; t\right) d X,
$$

where

$$
d X \equiv d x_{1} d y_{1} \cdots d x_{N} d y_{N} .
$$

In general, $\rho$ and $S_{\mathrm{e}}$ change during the evolution generated by the baker's map and depend on the initial $\rho$. However, if the initial probability-density function has a form

$$
\rho\left(x_{1}, y_{1} ; \ldots ; x_{N}, y_{N}\right)=\rho\left(x_{1}, y_{1}\right) \cdots \rho\left(x_{N}, y_{N}\right),
$$

which corresponds to an uncorrelated density function, then the probability-density function remains uncorrelated during the evolution.

As an example, consider $\rho\left(x_{l}, y_{l}\right)$ which is uniform within some subregion $\Sigma$ (with area $A<1$ ) of the unit square, and vanishes outside of $\Sigma$. In other words, let

$$
\rho\left(x_{l}, y_{l}, t\right)=\left\{\begin{array}{l}
1 / A \text { for }\left(x_{l}, y_{l}\right) \text { inside } \Sigma, \\
0 \quad \text { for }\left(x_{l}, y_{l}\right) \text { outside } \Sigma .
\end{array}\right.
$$

In this case

$$
S_{\mathrm{e}}=-\left(\frac{1}{A}\right)^{N} \log \left(\frac{1}{A}\right)^{N} A^{N}=N \log A .
$$

Since $A$ does not change during the baker's map evolution, we see that $S_{\mathrm{e}}$ is constant during the baker's map evolution. This example can be used to show that $S_{\mathrm{e}}$ is, in fact, constant for arbitrary initial probability function. To briefly sketch the proof, let us divide the unit $2 N$-dimensional box into a large number of small regions $\Sigma_{a}$, on each of which the probability is equal to $\rho_{a}$. During the evolution, each region $\Sigma_{a}$ changes the shape, but its $2 N$-dimensional "area" $A_{a}$ remains the same. Moreover, the probability $\rho_{a}$ on the new $\Sigma_{a}$ also remains the same. Consequently, the ensemble entropy $S_{\mathrm{e}}=-\sum_{a} A_{a}^{N} \rho_{a} \log \rho_{a}$ remains the same as well. This is the basic idea of a discrete version of the proof, but a continuous version can be done in a similar way. 


\subsection{Appropriate and inappropriate macroscopic variables}

The macroscopic variables defined in the preceding subsection have the following properties:

1. For most initial microstates having the property $S_{\mathrm{m}}<S_{\mathrm{m}}^{\max }, S_{\mathrm{m}}$ increases during the baker's map.

2. For most initial microstates having the property $S_{\mathrm{m}}=S_{\mathrm{m}}^{\max }, S_{\mathrm{m}}$ remains constant during the baker's map.

3. The two properties above do not change when the baker's map is perturbed by a small noise.

We refer to macrovariables having these properties as appropriate macrovariables. (They are "appropriate" in the sense that an appropriate macroscopic law of entropy-increase can be obtained only when macrovariables obey these properties.)

Naively, one might think that any seemingly reasonable choice of macrovariables is appropriate. Yet, this is not really the case. Let us demonstrate this by an example. Let us divide the unit square into $2^{M}$ equal vertical strips $(M \gg 1)$. We define a new set of macrovariables as the numbers of particles inside each of these strips. Similarly to (1), the corresponding macroscopic entropy is

$$
S_{\mathrm{m}}=-\sum_{k=1}^{2^{M}} N_{k} \log \left(\frac{N_{k}}{N}\right),
$$

where $N_{k}$ is the number of particles in strip $k$. For the initial condition, assume that the gas is uniformly distributed inside odd vertical strips, while even strips are empty. Then $S_{\mathrm{m}}<S_{\mathrm{m}}^{\max }$ initially. Yet, for a long time during the baker's evolution, $S_{\mathrm{m}}$ does not increase for any initial microstate corresponding to this macrostate. However, during this evolution the number of filled strips decreases and their thickness increases, until only one thick filled vertical strip remains. After that, $S_{\mathrm{m}}$ starts to increase. We also note that the evolution towards the single strip can be easily destroyed by a small perturbation.

Thus we see that vertical strips lead to inappropriate macrovariables. By contrast, horizontal strips lead to appropriate macrovariables. (Yet, the macrovariables in (11) are even more appropriate, because they lead to much faster growth of $S_{\mathrm{m}}$.) This asymmetry between vertical and horizontal strips is a consequence of the intrinsic asymmetry of the baker's map with respect to vertical and horizontal coordinates. This asymmetry is analogous to the asymmetry between canonical coordinates and momenta in many realistic Hamiltonian systems of classical mechanics. Namely, most realistic Hamiltonian systems contain only local interaction between particles, where locality refers to a separation in the coordinate (not momentum!) space.

Finally, we note that evolution of the macroscopic variables $N_{k}(t), k=1,2,3,4$, is found by averaging over ensemble in the following way

$$
N_{k}(t)=\int N_{k}\left(x_{1}, y_{1} ; \ldots ; x_{N}, y_{N} ; t\right) \rho\left(x_{1}, y_{1} ; \ldots ; x_{N}, y_{N} ; t\right) d X
$$




\subsection{Coarsening}

As we have already said, the ensemble entropy (unlike macroscopic entropy) is always constant during the baker's map evolution. One would like to have a modified definition of the ensemble entropy that increases similarly to the macroscopic entropy. Such a modification is provided by coarsening, which can be defined by introducing a coarsened probability-density function

$$
\begin{aligned}
\rho^{\text {coar }}\left(x_{1}, y_{1} ; \ldots ; x_{N}, y_{N}\right)= & \int \Delta\left(x_{1}-x_{1}^{\prime}, y_{1}-y_{1}^{\prime} ; \ldots ; x_{N}-x_{N}^{\prime}, y_{N}-y_{N}^{\prime}\right) \\
& \times \rho\left(x_{1}^{\prime}, y_{1}^{\prime} ; \ldots ; x_{N}^{\prime}, y_{N}^{\prime}\right) d X^{\prime}
\end{aligned}
$$

where $\Delta$ is nonvanishing in some neighborhood of $X^{\prime}=0,0 ; \ldots ; 0,0$. In this way, the coarsened ensemble entropy is

$$
S_{\mathrm{e}}^{\text {coar }}=-\int \rho^{\text {coar }}\left(x_{1}, y_{1} ; \ldots ; x_{N}, y_{N}\right) \log \rho^{\text {coar }}\left(x_{1}, y_{1} ; \ldots ; x_{N}, y_{N}\right) d X .
$$

Of course, the function $\Delta$ can be chosen in many ways. In the following we discuss a few examples.

One example is the Boltzmann coarsening, defined by

$$
\rho^{\mathrm{coar}}\left(x_{1}, y_{1} ; \ldots ; x_{N}, y_{N}\right)=\rho\left(x_{1}, y_{1}\right) \cdots \rho\left(x_{N}, y_{N}\right)
$$

where

$$
\rho\left(x_{1}, y_{1}\right)=\int \rho\left(x_{1}, y_{1} ; \ldots ; x_{N}, y_{N}\right) d x_{2} d y_{2} \cdots d x_{N} d y_{N}
$$

and similarly for other $\rho\left(x_{l}, y_{l}\right)$.

Another example is isotropic coarsening, having a form

$$
\begin{gathered}
\Delta\left(x_{1}-x_{1}^{\prime}, y_{1}-y_{1}^{\prime} ; \ldots ; x_{N}-x_{N}^{\prime}, y_{N}-y_{N}^{\prime}\right)= \\
\Delta\left(x_{1}-x_{1}^{\prime}\right) \Delta\left(y_{1}-y_{1}^{\prime}\right) \cdots \Delta\left(x_{N}-x_{N}^{\prime}\right) \Delta\left(y_{N}-y_{N}^{\prime}\right) .
\end{gathered}
$$

Yet another example is the Prigogine coarsening [22]

$$
\Delta\left(x_{1}-x_{1}^{\prime}, y_{1}-y_{1}^{\prime} ; \ldots ; x_{N}-x_{N}^{\prime}, y_{N}-y_{N}^{\prime}\right)=\Delta\left(y_{1}-y_{1}^{\prime}\right) \cdots \Delta\left(y_{N}-y_{N}^{\prime}\right) \text {, }
$$

which is an anisotropic coarsening over the shrinking direction $y$.

Finally, let us mention the coarsening based on dividing the system into two smaller interacting subsystems. The coarsened ensemble entropy for the full system is defined as the sum of uncoarsened ensemble entropies of its subsystems. Such a coarsened entropy ignores the correlations between the subsystems.

All these types of coarsening have the following property: If the initial microstate is such that macroscopic entropy increases, then the coarsened ensemble entropy also increases for that initial microstate. Yet, the Prigogine coarsening has the following advantages over Boltzmann and isotropic coarsenings:

First, if the initial microstate is such that the macroscopic entropy decreases, then the Prigogine coarsened ensemble entropy does not decrease, while the Boltzmann and isotropic coarsened ensemble entropies decrease. 
Second, assume that the initial microstate is such that the macroscopic entropy increases, and consider some "final" state with a large macroscopic entropy close to the maximal one. After this final state, consider the corresponding "inverted" state, (i.e., the state with exchanged $x$ and $y$ ). In the transition to this "inverted" state, the Prigogine coarsened ensemble entropy decreases, while the Boltzmann and isotropic coarsened ensemble entropies remain unchanged.

Thus, the Prigogine coarsening provides the most correct description of the ensembleentropy increase law without any additional assumptions. For example, to get the same result with Boltzmann coarsening, one would need to introduce the additional "molecular chaos hypothesis" to replace $\rho\left(x_{1}, y_{1} ; x_{2}, y_{2}\right)$ with $\rho\left(x_{1}, y_{1}\right) \rho\left(x_{2}, y_{2}\right)$ in the equation of motion for $\rho(x, y, t)$.

\section{The effects of weak interactions}

\subsection{Small external perturbations}

The growth of the ensemble entropy can be achieved even without coarsening, by introducing a small external perturbation of the baker's map. The perturbation must be small enough to avoid destruction of the growth of macroscopic entropy, but at the same time, it must be strong enough to destroy the reverse processes and Poincare returns. For most such perturbations, the qualitative features of the evolution do not depend much on details of the perturbation.

There are two ways how the external perturbation can be introduced. One way is to introduce a small external random noise. The macroscopic processes with the increase of macroscopic entropy are stable under such a noise. However, the area of a region is no longer invariant under the perturbed baker's map. In this way the ensemble entropy can increase.

The other way is to introduce a weak interaction with the environment (which can be thought of as an "observer"). Again, the macroscopic processes with the increase of macroscopic entropy are stable, but the area of a region is no longer invariant under the perturbed baker's map. Consequently, the ensemble entropy can increase. However, such a system is no longer isolated. Instead, it is a part of a larger system divided into two subsystems. Hence, as we have already explained in Sec. 3.3, the coarsened ensemble entropy for the full system can be defined as the sum of uncoarsened ensemble entropies of its subsystems. In the next subsection we study the weak interactions with the environment in more detail.

\subsection{Weak interaction and the destruction of opposite time ar- rows}

To proceed, one needs to choose some specific interaction between two gases. In the absence of interaction, each of them evolves according to the baker's map. We put the two unit squares one above another and specify the interaction with the range of interaction $\sigma$, such that, between two steps of the baker's map, all closest pairs of particles (with distance smaller than $\sigma$ between them) exchange their positions. (More precisely, we 
first find the pair of closest particles (with distance smaller than $\sigma$ between them) and exchange their positions. After that, we find the second pair of closest particles (with distance smaller than $\sigma$ between them and different from previously chosen particles) and exchange their positions too. We repeat this procedure until we exhaust all particles.) The interaction happens only between the particles in different subsystems because it makes no sense to introduce such interaction within a single subsystem. Namely, such an interaction does not affect the motion of the particles, but only gives rise to the mixing between the two subsystems when two particles of the pair belong to different subsystems. When they belong to the same system, we interpret them as trivial irrelevant exchanges, and consequently think of them as exchanges that have not happened at all.

Note also that such mixing by itself does not lead to the Gibbs paradox, as long as we consider the two unit squares as separate objects. The macroscopic entropy is defined as the sum of macroscopic entropies of the two subsystems.

Now let us consider the case in which the time arrows of the two subsystems have the same direction. The processes in which the macroscopic entropies of the two subsystems increase are stable under the interaction. Thus, most low-entropy initial conditions lead to a growth of macroscopic entropy of both subsystems, as well as of the full system.

Similarly, if we inverse a process above with increasing macroscopic entropy, we obtain a system in which macroscopic entropy of both subsystems, as well as of the full system - decreases. In this sense, the interaction does not ruin the symmetry between the two directions of time.

Now let us consider the most interesting case, in which entropy increases in the first subsystem and decreases in the second. The initial state of the first subsystem has a low entropy (for example, all particles are in some small square near the point $(0,0)$ of the unit square). Likewise, the second system has a low entropy (for example, all particles are in some small square near the point $(1,1)$ of the unit square) in the final state.

If there was no interaction, the final state of the first subsystem would be a highentropy state corresponding to a nearly uniform distribution of particles. Likewise, the initial state of the second system would be a high-entropy state of the same form.

However, the solutions above with two opposite arrows of time are no longer solutions when the interaction is present. In most cases, the interaction mixes the particles between the subsystems. The number of solutions with interaction which have the initial-final conditions prescribed above is very small, in fact much smaller than the number of such solutions in the absence of interaction.

Let us make the last assertion more quantitative. After an odd number of (non-trivial) exchanges, the particle transits to the other subsystem. Likewise, after an even number of such exchanges, it remains in the same subsystem. The probabilities for these two events are equal to $p=1 / 2$ and do not depend on other particles, at least approximately. Further, we can argue that the mixing between the two subsystems is negligible in the initial and final states, as the entropies of the two subsystems are very different. We want to calculate the probability of a small mixing in the final state, given that the mixing is small in the initial state. For definiteness, we shall say that the mixing is small if the number $N_{t}$ of transited particles is either $N_{t}<N / 4$ or $N_{t}>3 N / 4$. (Recall that the particle exchange is the only effect of our perturbation, so mixing cannot depend on any other variable except $N_{t}$. The factors $1 / 4$ and $3 / 4$ are, of course, chosen arbitrarily, but we fix them in order to get some concrete results in a simple final form. The qualitative 
results that follow do not depend on this choice.) Thus, the probability is given by the cumulative binomial distribution $F\left(N_{t} ; N, 1 / 2\right)$, given by

$$
F(k ; n, p)=\sum_{i=0}^{\lfloor k\rfloor}\left(\begin{array}{l}
n \\
i
\end{array}\right) p^{i}(1-p)^{n-i}
$$

where $\lfloor k\rfloor$ is the greatest integer less than or equal to $k$. The function $F(k ; n, p)$ satisfies the bound

$$
F(k ; n, p) \leq \exp \left(-2 \frac{(n p-k)^{2}}{n}\right) .
$$

Thus, since the opposite time arrows of subsystems are not destroyed when $N_{t}<N / 4$ or $N_{t}>3 N / 4$, we see that the probability of this is equal to

$$
2 F(N / 4 ; N, 1 / 2) \leq 2 e^{-N / 8} .
$$

Clearly, it decreases exponentially with $N$, which means that such a probability is negligibly small for large $N$. Hence, it is almost certain that processes with opposite time arrows will be destroyed.

In the model above, we need a nearly equal number of particles in the two subsystems to destroy the opposite time arrows. This is because one particle can influence the motion of only one close particle. For more realistic interactions, one particle can influence the motion of a large number of particles in its neighborhood, which means that even a very small number of particles in one system can destroy the entropy decreasing processes of the other system.

\subsection{Decorrelation in the interacting system}

Hamiltonian systems are described not only by a macrostate, but also by complex nonlinear correlations between microstates. These correlations are responsible for reversibility. The interaction between two subsystems destroys these correlations inside the subsystems, but the full system remains reversible, i.e., the correlations appear in the full system. Thus, the decorrelation in the subsystems spreads the correlations over the full system. (This process is a classical analogue of decoherence in quantum mechanics.)

Let us put these qualitative ideas into a more quantitative form. Linear (Pearson) correlations have a behavior very similar to the nonlinear correlations described above. The only difference is that these linear correlations decrease with time. The interaction we proposed can be approximated by a random noise with amplitude corresponding to the range of interaction $\sigma$ between the particles. Therefore, we expect that the interaction not only causes the alignment of the time arrows, but also a decay of correlation which is even stronger than that without the interactions (Sec. A.5). During this process the evolution of subsystems is irreversible, but the full system remains reversible.

We can quantify this decay of correlations by calculating the Pearson correlation for our subsystems, given by

$$
r(m)=\frac{C(m)}{\sqrt{C(0)\left\langle C^{m}(0)\right\rangle}},
$$


where $\left\langle C^{m}(0)\right\rangle$ is the expected variance of the random variable $x$ calculated after $m$ iterations of the map. The variance $C^{m}(0)$ can be calculated as

$$
C^{m}(0)=\sum_{j=0}^{2^{m}-1} \int_{j 2^{-m}}^{(j+1) 2^{-m}}\left(2^{m} x-j-\langle x\rangle+S\right)^{2} d x
$$

where $S$ is a random number defined as $S=\sum_{k=0}^{m-1} 2^{k} \zeta_{k}$. Here $\zeta_{k}$ is an i.i.d. random number with zero mean and variance $\sigma^{2}$, which models the influence of interactions on the evolution of the system. After a short calculation we get

$$
\left\langle C^{m}(0)\right\rangle=C(0)+\left\langle S^{2}\right\rangle=C(0)+\sum_{k, k^{\prime}=0}^{m-1} 2^{k+k^{\prime}}\left\langle\zeta_{k} \zeta_{k^{\prime}}\right\rangle .
$$

Using the properties of i.i.d. variables $\left\langle\zeta_{k} \zeta_{k^{\prime}}\right\rangle=\delta_{k k^{\prime}} \sigma^{2}$, it follows that

$$
\left\langle C^{m}(0)\right\rangle=C(0)+\frac{2^{2 m}-1}{3} \sigma^{2} .
$$

It is clear that the interactions will enhance the decay of correlations of at least linear dependencies, because

$$
r(m)=\frac{2^{-m}}{\sqrt{1+4\left(2^{2 m}-1\right) \sigma^{2}}} .
$$

Yet, for the full system the Pearson correlation $r(m)=2^{-m}$ remains the same. Since $\left\langle S^{2}\right\rangle^{1 / 2}$ must be much smaller than the system size (unit square), we can conclude that our assumptions resulting in (22) are correct only for $\left\langle S^{2}\right\rangle=\left[\left(2^{2 m}-1\right) / 3\right] \sigma^{2} \ll 1$ and $\sigma^{2} / 2^{-2 m} \ll 1$

\subsection{Numerical simulation}

So far, we have been using general abstract arguments. In this subsection we support these arguments by a concrete numerical simulation. We consider two subsystems (labeled as 1 and 2), each with $N_{1}=N_{2}=300$ particles. The two subsystems occupy two unit squares. To define the coarsened entropy, each unit square is divided into $16 \times 16=256$ small squares. Thus, the entropy in the two subsystems is given by

$$
S_{i}=-N_{i} \sum_{k=1}^{512} f_{k, i} \log f_{k, i}
$$

where $i=1,2, f_{k, i}=n_{k, i} / N_{i}$, and $n_{k, i}$ is the number of particles in the corresponding small square. Similarly, the total entropy is defined as

$$
S=-\left(N_{1}+N_{2}\right) \sum_{k=1}^{512} f_{k} \log f_{k}
$$

where $f_{k}=\left(n_{k, 1}+n_{k, 2}\right) /\left(N_{1}+N_{2}\right)$

For the system 1 we choose a zero-entropy initial state at $t=1$ (see Fig. 11). Similarly, for the system 2 we choose a zero-entropy "initial" state at $t=6$. Such initial conditions 

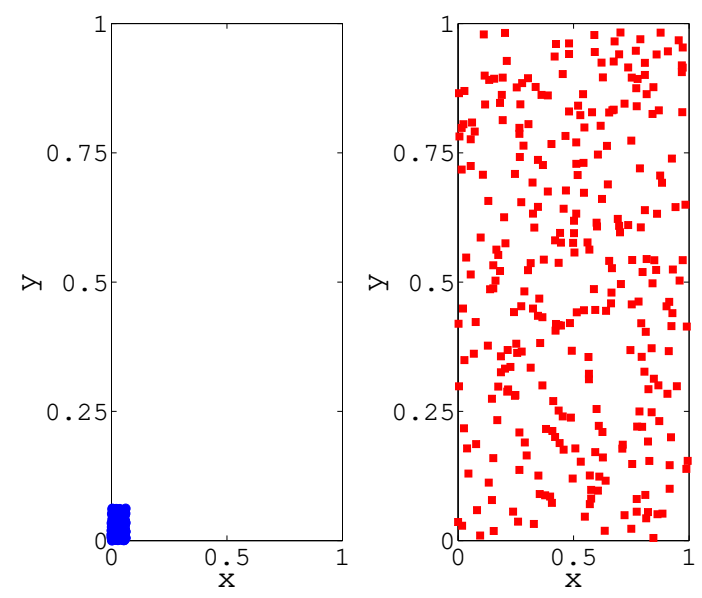

Figure 1: The initial particle configuration at $t=1$.

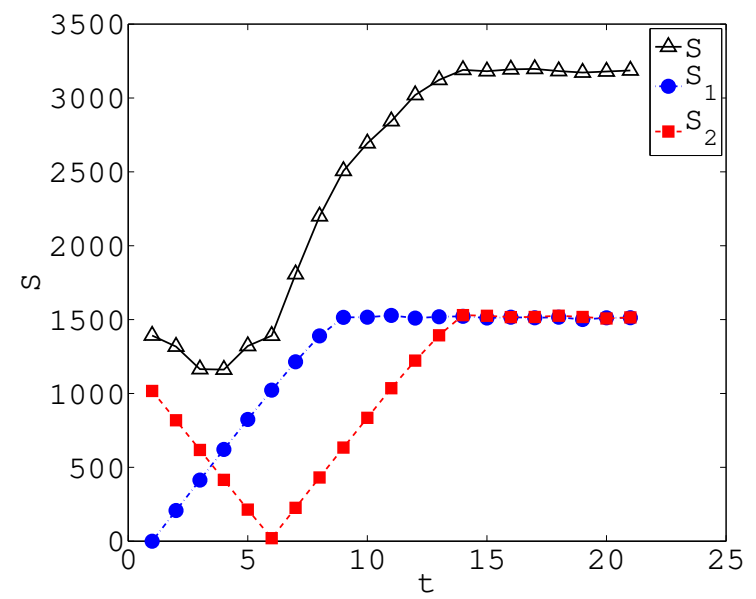

Figure 2: Evolution of entropy without interaction.

provide that, in the absence of interactions, $S_{1}$ increases with time, while $S_{2}$ decreases with time for $t<6$. To avoid numerical problems arising from the finite precision of computer representation of rational numbers, (27) is replaced by $x^{\prime}=a x-\lfloor a x\rfloor, y^{\prime}=(y+\lfloor a x\rfloor) / 2$, with $a=1.999999$. The results of a numerical simulation are presented in Fig. 1 and Fig. 2,

To include the effects of interaction, we define interaction in the following way. (For the sake of computational convenience, it is defined slightly differently than in Sec. 4.2. The interaction used in Sec. 4.2 is chosen to make the analytical calculations simpler, while that in the present section is chosen to make the numerical computations simpler.) We take a small range of interaction $r_{y}=0.01$ in the $y$-direction, which can be thought of as a parameter that measures the weakness of interaction. (Recall that $y$ and $x$ are analogous to a canonical coordinate and a canonical momentum, respectively, in a Hamiltonian phase space.) The interaction exchanges the closest pairs similarly as in Sec. 4.2, but now "the closest" refers to the distance in the $y$-direction, and there is no exchange if the 


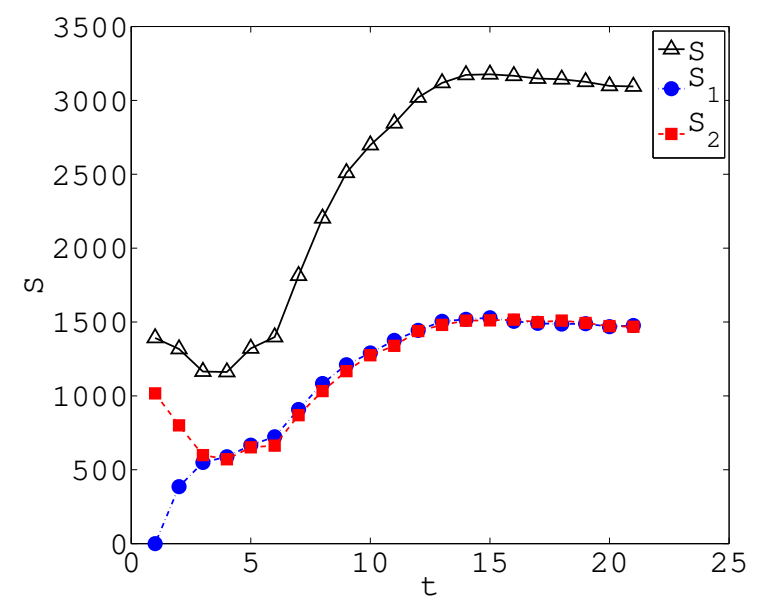

Figure 3: Evolution of entropy with interaction.

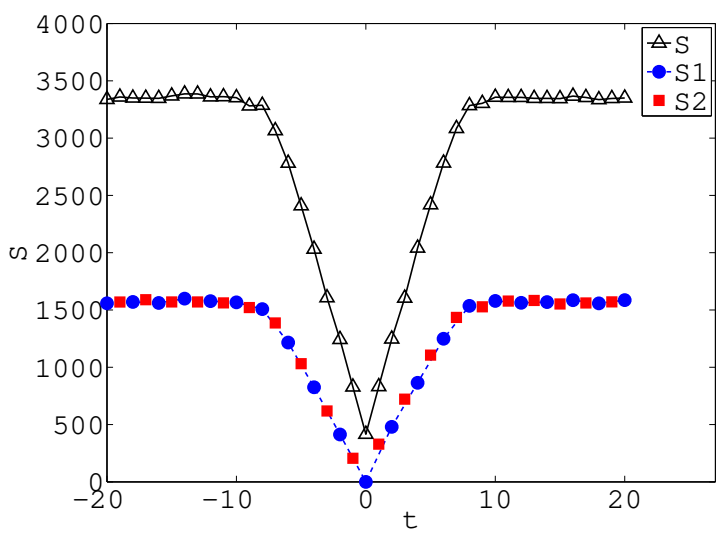

Figure 4: A symmetric evolution of entropy with interaction.

closest distance is larger than $r_{y}$. In addition, now interaction is defined such that only the $x$-coordinates of the particles are exchanged. By choosing the same initial conditions at $t=1$ as in the non-interacting case (Fig. 1), the results of a numerical simulation with the interaction are presented in Fig. 3. We see that with interaction (Fig. 3) $S_{2}$ starts to increase at earlier times than without interaction (Fig. 2).

Finally, we present an example of a symmetric time evolution with interaction. For that purpose, we choose a zero-entropy initial state at $t=0$ for both system 1 and system 2. The two initial zero-entropy configurations are different. In particular, they are located within two different small squares, so that the total initial entropy is larger than zero. The result of a numerical simulation is presented in Fig. 4. We see that the solution is symmetric under the time inversion $t \rightarrow-t$. 


\section{Discussion}

In this paper, we have used the toy model based on the baker's map to demonstrate features which seem to be valid for general systems described by reversible Hamiltonian mechanics. Clearly, for such systems one can freely choose either final or initial conditions, but one cannot freely choose mixed initial-final conditions. (For mixed initial-final conditions, the canonical variables are fixed at an initial time for some of the particles, but at an final time for the other particles. For most such mixed initial-final conditions, an appropriate solution (of the Hamiltonian equations of motion) does not exist. Similarly, our toy model suggests that for most Hamiltonians with weak interactions, the number of solutions with given coarse-grained initial-final conditions is much smaller then the number of solutions with only coarse-grained initial or only coarse-grained final conditions. This explains why, in practice, we almost never observe subsystems with opposite arrows of time, i.e., why the arrow of time is universal.

In a sense, this destruction of opposite arrows of time is similar to ergodicity. Both properties are valid for most practical purposes only, they are not exact laws. They are true for most real systems, but counterexamples can always be found [26, 27]. Also, they both may seem intuitively evident, but to prove them rigorously is very difficult. For ergodicity the relevant rigorous result is the KAM (Kolmogorov-Arnold-Moser) theorem, while for the destruction of the opposite time arrows a rigorous theorem is still lacking.

Our results also resolve the "contradiction" between the Prigogine's "New Dynamics" [22] (discussed in Sec. 3.3 of the present paper) and Bricmont's comments [28]. Dynamics of interacting systems can be divided into two types of dynamics:

1. Reversible ideal dynamics is considered with respect to the coordinate time, in which case entropy can either decrease or increase.

2. Irreversible observable dynamics is considered with respect to the intrinsic time arrows of interacting systems, in which case entropy increases as we can see above. (In other words, the entropy increases rather than decreases with $t$ because the orientation of $t$ is defined as a direction in which entropy increases.)

In the framework of this terminology, the Prigogine's "New Dynamics" [22] is one of the forms of the observable dynamics, while the Bricmont's paper [28] considers ideal dynamics. In particular, the observable dynamics does not include Poincare's returns and reversibility, that are indeed unobservable by a real observer, which makes it simpler than ideal dynamics. Yet, in principle, both types of dynamics are correct.

This reasoning can also be applied to the interpretation of numerical results in Sec.4.4. Both Fig. 2 and Fig. 3 show that the arrow of time, defined by the total entropy, reverses at some point. This reversal corresponds to the description by ideal dynamics. But can such a reversal be observed? For the sake of conceptual clarity we stress that the observer is nothing but one of the subsystems, and split the question into three different ones. First, can the observer observe the reversal of his own arrow of time? Second, can the observer observe the reversal of time arrow of his total environment? Third, can the observer observe the reversal of time arrow of a small part of his environment?

The answer to the first question is no, because the observer naturally defines the arrow of time as the direction in which his own entropy increases. Namely, the observer 
perceives a subjective experience of the flow of time because at each time he has access to his memory on some events which are not happening right now. Such events are naturally interpreted as "past" by him. It can be argued that memory can only work when entropy increases in the direction from the memorized event to the time of recalling it (see, e.g., [20]). Similarly, other processes in the brain (or a computer) also seem to require an increase of entropy for their normal way of functioning (see also [3]). In this way, one expects that the observer's subjective experience of the flow of time always coincides with the direction in which the observer's entropy increases.

The answer to the second question is almost certainly no, because if the total environment is observed then it interacts with the observer, and consequently their time arrows tend to be aligned, except, perhaps, during a very short time needed for the process of aligning.

The answer to the third question is sometimes yes, but usually no. Namely, some special systems (e.g., the spin-echo system discussed in Sec. 2) can weakly interact with its environment and still retain a time arrow opposite to that of its environment for a relatively long time. Such special systems are relatively small parts of the total environment, and the observer can observe that such a subsystem has a time arrow opposite to that of the observer. Indeed, as we have already explained in Sec. 2, our results based on probabilistic reasoning on typical systems do not imply that it is absolutely impossible to observe a subsystem in which entropy decreases. They only explain why such systems are expected to be very rare, which agrees with everyday experience.

A closely related observation is that our results are not in contradiction with the existence of dissipative systems [29] (such as certain self-organizing biological systems) in which entropy of a subsystem can decrease with time, despite the fact that entropy of the environment increases. The full-system entropy (including the entropies of both the dissipative system and the environment) increases, which is consistent with the entropyincrease law. For such systems, it is typical that the interaction with the environment is strong, while results of our paper refer to weak interactions between the subsystems. For example, for existence of living organisms, a strong energy flow from the Sun is needed. The small flow from other stars is not sufficient for life, but is sufficient for the decorrelation and for the alignment of the time arrows. To quote from [6]: "However, an observer is macroscopic by definition, and all remotely interacting macroscopic systems become correlated very rapidly (e.g. Borel famously calculated that moving a gram of material on the star Sirius by $1 \mathrm{~m}$ can influence the trajectories of the particles in a gas on earth on a time scale of $\mu \mathrm{s}$ [30])."

\section{Acknowledgements}

The authors are grateful to the anonymous referees for various suggestions to improve the clarity of the paper. The works of H.N. and V.Z. was supported by the Ministry of Science of the Republic of Croatia under Contracts No. 098-0982930-2864 and 098-0352828-2863, respectively. 


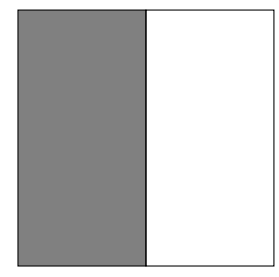

(a)

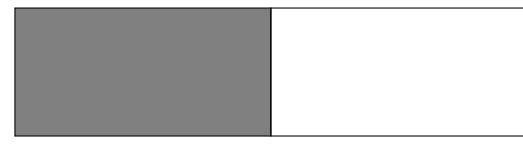

(b)

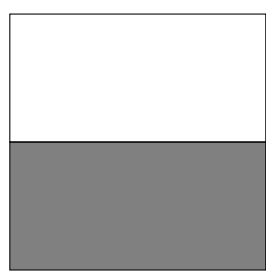

(c)

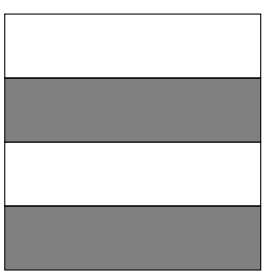

(d)

Figure 5: Geometric interpretation of the baker's map. (a) Initial configuration. (b) Uniform squeezing in vertical direction and stretching in horizontal direction by a factor of 2. (c) The final configuration after cutting the right half and putting it over the left one. (d) The final configuration after two iterations.

\section{A Basic properties of the baker's map}

In this appendix we present some basic properties of the baker's map. More details can be found, e.g., in [31].

\section{A.1 Definition of the baker's map}

Consider a binary symbolic sequence

$$
\ldots S_{-2}, S_{-1}, S_{0} ; S_{1}, S_{2}, S_{3} \ldots
$$

infinite on both sides. Such a sequence defines two real numbers

$$
x=0 . S_{1} S_{2} S_{3} \ldots, \quad y=0 . S_{0} S_{-1} S_{-2} \ldots
$$

The sequence can be moved reversibly with respect to the semicolon in both directions. After the left shift we get new real numbers

$$
x^{\prime}=2 x-\lfloor 2 x\rfloor, \quad y^{\prime}=\frac{1}{2}(y+\lfloor 2 x\rfloor),
$$

where $\lfloor x\rfloor$ is the greatest integer less than or equal to $x$. This map of unit square into itself is called the baker's map.

The baker's map has a simple geometrical interpretation presented in Fig. 5. There (a) is the initial configuration and (c) is the final configuration after one baker's iteration, with an intermediate step presented in (b). The (d) part represents the final configuration after two iterations.

\section{A.2 Unstable periodic orbits}

The periodic symbolic sequences $(0)$ and (1) correspond to fixed points $(x, y)=(0,0)$ and $(x, y)=(1,1)$, respectively. The periodic sequence (10) corresponds to the period-2 orbit $\{(1 / 3,2 / 3),(2 / 3,1 / 3)\}$. From periodic sequence ...001; $001 \ldots$ we get $\{(1 / 7,4 / 7),(2 / 7,2 / 7),(4 / 7,1 / 7)\}$. Similarly, from ...011;011 ... we get $\{(3 / 7,6 / 7),(6 / 7,3 / 7),(5 / 7,5 / 7)\}$. 
Any $x$ and $y$ can be approximated arbitrarily well by $0 . X_{0} \ldots X_{n}$ and $0 . Y_{0} \ldots Y_{m}$, respectively, provided that $n$ and $m$ are sufficiently large. Therefore the periodic sequence $\left(Y_{m} \ldots Y_{0} X_{0} \ldots X_{n}\right)$ can approach any point of the unit square arbitrarily close. Thus, the set of all periodic orbits makes a dense set on the unit square.

\section{A.3 Ergodicity, mixing, and area conservation}

Due to stretching in the horizontal direction, all close points diverge exponentially under the baker's iterations. In these iterations, a random symbolic sequence approaches any point of the square arbitrarily close. In general, such an ergodic property can be used to replace the "time" average $\langle A\rangle$ by the "ensemble" average

$$
\langle A\rangle=\sum_{n} A\left(x_{n}, y_{n}\right)=\int A(x, y) d \mu(x, y)=\int A(x, y) \rho(x, y) d x d y
$$

where $d \mu(x, y)$ is the invariant measure and $\rho(x, y)$ is the invariant density for the map. For the baker's map, $\rho(x, y)=1$.

Under the baker's iterations, any region maps into a set of narrow horizontal strips. Eventually, it fills uniformly the whole unit square, which corresponds to mixing. Similarly, reverse iterations map the region into narrow vertical strips, which also corresponds to mixing.

During these iterations, the area of the region does not change. This property is the area conservation law for the baker's map.

\section{A.4 Lyapunov exponent, shrinking and stretching directions}

If $x_{0}^{(1)}$ and $x_{0}^{(2)}$ have equal $k$ first binary digits, then, for $n<k$,

$$
x_{n}^{(2)}-x_{n}^{(1)}=2^{n}\left(x_{0}^{(2)}-x_{0}^{(1)}\right)=\left(x_{0}^{(2)}-x_{0}^{(1)}\right) e^{n \log 2},
$$

where $\Lambda=\log 2$ is the first positive Lyapunov exponent for the baker's map. Consequently, the distance between two close orbits increases exponentially with increasing $n$, and after $k$ iterations becomes of the order of 1 . This property is called sensitivity to initial conditions. Due to this property, all periodic orbits are unstable.

Since the area is conserved, the stretching in the horizontal direction discussed above implies that some shrinking direction must also exist. Indeed, the evolution in the vertical $y$ direction is opposite to that of the horizontal $x$ direction. If $\left(x_{0}^{(1)}, y_{0}^{(1)}\right)$ and $\left(x_{0}^{(2)}, y_{0}^{(2)}\right)$ are two points with $x_{0}^{(1)}=x_{0}^{(2)}$, then

$$
y_{n}^{(2)}-y_{n}^{(1)}=2^{-n}\left(y_{0}^{(2)}-y_{0}^{(1)}\right)=\left(y_{0}^{(2)}-y_{0}^{(1)}\right) e^{n(-\log 2)} .
$$

Hence $\Lambda=-\log 2$ is the second negative Lyapunov exponent for the baker's map.

\section{A.5 Decay of correlations}

Since $x$-direction is the unstable direction, the evolution in that direction exhibits a decay of correlations. The average correlation function $C(m)$ for a sequence $x_{k}$ is usually defined 
as

$$
C(m)=\lim _{n \rightarrow \infty} \frac{1}{n} \sum_{k=1}^{n}\left(x_{k}-\langle x\rangle\right)\left(x_{k+m}-\langle x\rangle\right),
$$

where $\langle x\rangle=\lim _{n \rightarrow \infty} \sum_{k=1}^{n} x_{k} / n$. Correlations can be more easily calculated if one knows the invariant measure $\mu(x)$, in which case

$$
C(m)=\int(x-\langle x\rangle)\left(f^{m}(x)-\langle x\rangle\right) d \mu(x)
$$

where $f^{m}(x)=x_{m}$ is the function that maps the variable $x$ to its image after $m$ iterations of the map. For the baker's map $d \mu(x)=d x$, so we can write

$$
C(m)=\sum_{j=0}^{2^{m}-1} \int_{j 2^{-m}}^{(j+1) 2^{-m}}(x-\langle x\rangle)\left(2^{m} x-j-\langle x\rangle\right) d x
$$

which yields

$$
C(m)=\sum_{j=0}^{2^{m}-1}\left[2^{m} \frac{x^{3}}{3}-\left(2^{m}\langle x\rangle+\langle x\rangle\right) \frac{x^{2}}{2}+\langle x\rangle^{2} x-j\left(\frac{x^{2}}{2}-\langle x\rangle x\right)\right]_{j 2^{-m}}^{(j+1) 2^{-m}}
$$

For the baker's map $\langle x\rangle=1 / 2$, so the sum above can be calculated explicitly

$$
C(m)=\frac{2^{-m}}{12}
$$

This shows that the correlations decay exponentially with $m$. The Pearson correlation for the system is given by

$$
r(m)=C(m) / C(0)=2^{-m}
$$

\section{References}

[1] H. Reichenbach, The Direction of Time (University of California Press, Los Angeles, 1971).

[2] P.C.W. Davies, The Physics of Time Asymmetry (Surrey University Press, London, 1974).

[3] R. Penrose, The Emperor's New Mind (Oxford University Press, 1989).

[4] H. Price, Time's Arrow and Archimedes' Point (Oxford University Press, New York, 1996).

[5] H.D. Zeh, The Physical Basis of the Direction of Time (Springer, Heidelberg, 2007).

[6] L. Maccone, Phys. Rev. Lett. 103, 080401 (2009).

[7] L. Vaidman, quant-ph/9609006.

[8] O. Kupervasser, nlin/0407033. 
[9] O. Kupervasser, nlin/0508025.

[10] D. Jennings, T. Rudolph, Phys. Rev. Lett. 104, 148901 (2010).

[11] O. Kupervasser, D. Laikov, arXiv:0911.2610.

[12] H. Nikolić, arXiv:0912.1947.

[13] L. Maccone, arXiv:0912.5394.

[14] H.D. Zeh, Entropy 7, 199 (2005).

[15] H.D. Zeh, Entropy 8, 44 (2006).

[16] O. Kupervasser, arXiv:0911.2076.

[17] W. Thomson, Proc. Roy. Soc. Edinburgh 8, 325 (1874); reprinted in S.G. Brush, Kinetic Theory (Pergamon, Oxford, 1966).

[18] J.L. Lebowitz, Turkish Journal of Physics 19, 1 (1995); cond-mat/9605183.

[19] G.F.R. Ellis, Gen. Rel. Grav. 38, 1797 (2006).

[20] H. Nikolić, Found. Phys. Lett. 19, 259 (2006).

[21] H. Nikolić, http://www.fqxi.org/data/essay-contest-files/Nikolic_FQXi_time.pdf.

[22] I. Prigogine, From Being to Becoming (W.H. Freeman and Company, New York, 1980)

[23] Y. Elskens, R. Kapral, J. Stat. Phys. 38, 1027 (1985).

[24] P. Gaspard, J. Stat. Phys. 68, 673 (1992).

[25] G.C. Hartmann, G. Radons, H.H. Diebner, O.E. Rossler, Discrete Dynamics in Nature and Society 5, 107 (2000).

[26] L.S. Schulman, Phys. Rev. Lett. 83, 5419 (1999).

[27] L.S. Schulman, Entropy 7, 208 (2005).

[28] J. Bricmont, chao-dyn/9603009.

[29] I. Prigogine, Self-organization in nonequilibrium systems (John Wiley \& Sons, 1977).

[30] E. Borel, Le Hasard (Alcan, Paris, 1914).

[31] D.J. Driebe, Fully Chaotic Maps and Broken Time Symmetry (Kluwer Academic Publishers, Dordrecht, 1999). 


\title{
Универсальная стрела времени I: Классическая механика
}

\author{
Олег Юрьевич Купервассер ${ }^{1}$, Hrvoje Nikolic ${ }^{2}$, Vinko Zlatic ${ }^{3}$ \\ ${ }^{1}$ Moscow State University, Scientific Research Computer Center \\ Moscow, Russia, ${ }^{1}$ Email: olegkup@yahoo.com \\ 2,3 Theoretical Physics Division, Rudjer Boskovic Institute \\ P.O.B. 180, HR-10002 Zagreb, Croatia \\ ${ }^{2}$ Email: hrvoje@thphys.irb.hr, ${ }^{3}$ Email: Vinko.Zlatic@irb.hr
}

Август 2011 


\section{Аннотация}

Статистическая физика не может объяснить, почему термодинамическая стрела времени существует, если не постулируются очень специальные и неестественные начальные условия. Однако, мы утверждаем, что статистическая физика может объяснить, почему термодинамическая стрела времени универсальна, то есть, почему стрела времени направлена в одинаковом направлении повсюду. А именно, если у двух подсистем есть противоположные направления стрелы времени первоначально, взаимодействие между ними делает конфигурацию статистически неустойчивой и вызывает переход к системе с универсальным направлением стрелы времени. Мы даем общие качественные аргументы в пользу такого взгляда и иллюстрируем их детальным анализом "игрушечной"модели, основанной на "Преобразовании Пекаря". 
PACS: 05.20.-y, 05.45.-a

Keywords: стрела времени, увеличение энтропии, преобразование Печника

\section{1 Введение}

Происхождение стрелы времени - одна из самых больших нерешенных загадок в физике [1 5]. Хорошо установлено, что большинство стрел времени может быть приведено к термодинамической стреле, но происхождение термодинамической стрелы времени остается тайной. А именно, существование термодинамической стрелы времени означает, что система не находится в состоянии с максимально возможной энтропией. Но это означает, что система не находится в самом вероятном состоянии, что не имеет никакого статистического объяснения. Факт увеличения энтропии со временем означает, что система была в даже менее вероятном состоянии в прошлом, что делает задачу еще более сложной. Конечно, рост энтропии со временем может быть описан, при предположении, что Вселенная была в состоянии с очень низкой энтропией вначале. Однако при этом никак нельзя объяснить, почему Вселенная началась с такого очень специального и неестественного начального условия.

В недавней статье Maccone [6] утверждал, что задача происхождения стрелы времени может быть решена квантовой механикой. Он показал, что в квантовой механике все явления, которые оставляют след в памяти наблюдателя (и, следовательно, могут быть изучены физикой) являются именно теми, при которых энтропия увеличивается. (Следует отметить, что аргумент о стирании памяти наблюдателя при убывании энтропии и соответствующие мысленные эксперименты, рассмотренные в [6] использовалась и в более ранних работах других авторов для разрешения парадокса роста энтропии и квантового парадокса редукции волнового пакета [7 9].) ]). Из этого Масcone заключает, что таким образом второй закон термодинамики сводится к простой тавтологии, автоматически решая проблему стрелы времени в физике. Однако, некоторые слабости аргументов, используемых Maccone в [6] указаны в статьях [10 12. Как ответ на одно из этих возражений, в более поздней публикации [13] сам Maccone понял, что его подход полностью не решает проблему происхождения стрелы времени, потому что квантовый механизм также требует крайне невероятных начальных условий, которые не могут быть объяснены, исходя из его аргументов.

Все же, как и Maccone в [13], мы полагаем, что некоторые идеи, представленные в [6] и [13] действительно помогают лучше понять проблему стрелы времени. Цель этой статьи состоит в том, чтобы далее разработать, улучшить, разъяснить, и расширить некоторые из идей, которые были представлены в [6,11,13, и также в несколько отличном контексте в [8,9,14 18]. В частности, в отличие от Maccone в [6, 13], мы утверждаем, что квантовая механика не является существенным фактором для разрешения этой проблемы. Поэтому в этой статье мы рассматриваем только классическую статистическую физику.

Идея разрешения этого парадокса следующая. Даже при том, что статистическая физика не может объяснить, почему термодинамическая стрела времени существует, по крайней мере, становится возможным объяснить, почему термодинамическая стрела времени универсальна. То есть, мы можем объяснить, почему стрела указывает в одинаковом направлении повсюду. А именно, 
если у двух подсистем есть противоположные направления стрелы времени первоначально, взаимодействие между ними делает конфигурацию статистически неустойчивой и вызывает переход к системе с универсальным направлением стрелы времени. Это, конечно, полностью не решает проблему происхождения стрелы времени. Но, по крайней мере, облегчает её решение.

Статья организована следующим образом. В следующем разделе мы представляем свои главные идеи в интуитивной нетехнической форме. После этого, в разделе 0.3 мы изучаем статистические свойства "Преобразования Пекаря"(некоторые основные свойства которого представлены в Приложении), которое служит "игрушечной"моделью для того, чтобы изучить характерные особенности обратимых хаотических Гамильтоновых систем. Как побочный результат, в этом разделе мы также проясняем разницу между различными определениями понятия "энтропии". Затем, в разделе 0.4 мы изучаем эффекты слабых взаимодействий между подсистемами, которые, без взаимодействия, эволюционируют согласно "Преобразованию Пекаря". В частности мы объясняем, как слабые взаимодействия разрушают противоположные стрелы времени подсистем, делая их намного менее вероятными, чем в случае без взаимодействия. Наконец, в разделе 0.5 мы даем качественное обсуждение наших результатов, включая их совместимость с наличием сильновзаимодействующих систем, в которых энтропия подсистемы может уменьшиться со временем.

\section{2 Главные идеи.}

Чтобы избегать двусмысленности в дальнейших обсуждениях, позвольте нам сначала объяснять наши основные понятия и терминологию, используемую в остальной части статьи. Для той цели полезно изобразить время как непрерывную 1-мерную линию. Линия параметризуется непрерывным параметром $t$. Такая параметризация обязательно создает ориентацию линии времени с направлением, указывающим от меньших к большим величинам $t$. Мы можем использовать эту ориентацию, чтобы определить понятия типа "прежде"и "после "прошлое"и "будущее или "начальный"и "заключительный". В этой статье, если не заявлено иначе, под этими понятиями мы подразумеваем понятия, определенные относительно этой временой координаты $t$. Однако, мы подчеркиваем, что такая ориентация времени координаты - просто вопрос выбора и не имеет никакого физического содержания. В частности, такая ориентация сама по себе не создает стрелу времени. Вместо этого, под стрелой времени мы подразумеваем физическое явление, как, например, увеличение или уменьшение энтропии со временем $t$. Когда стрела времени в одном и том же направлении всюду на линии времени, тогда временная координата может быть определена так, что ориентация $t$ совпадает со стрелой времени. Это позволяет нам злоупотреблять языком в некоторых местах, утверждая, что энтропия "увеличения а не "уменьшения"со временем, но нужно иметь в виду это, различие между увеличением и уменьшением со временем - просто вопрос определения. Вообще же, стрела времени и ориентации $t$ - логически независимые понятия.

Теперь позвольте нам обсудить термодинамическую стрелу времени. Априорно, вероятность наличия термодинамической стрелы времени очень низка. Однако идея состоит в том, чтобы думать в терминах условных вероятностей. Учитывая, что термодинамическая стрелка существует, что может мы, используя статистические аргументы, вывести из этого?

Чтобы ответить на этот вопрос, позвольте нам начать с законов микроско- 
пической теории. Мы предполагаем, что динамика микроскопических степеней свободы описана набором дифференциальных уравнений второго порядка (с производными по времени), которые являются инвариантными при обращении времени $t \rightarrow-t$. Таким образом, у обоих направлений времени есть априорно равные роли. Чтобы определить единственное решение уравнений динамики движения, также нужно выбрать некоторое "начальное"время $t_{0}$, на котором должны быть определены начальные условия. ("Начальное"время не обязательно должно быть самым ранним временем, в которое Вселенная вошла в существование. Для любого $t_{0}$, в котором определены начальные условия, уравнения динамики движения единственным образом определяют состояние Вселенной как для $t>t_{0}$, так и для $\left.t<t_{0}\right)$. Это - просто обычный специфический момент времени, который может быть взят даже в "будущем". Действительно, в этой статье мы принимаем картину "блочной Вселенной"(смотри, например, 4,19 21] и ссылки там), согласно которой время не "течет". Вместо этого Вселенная - это просто "статический"объект в 4-ёх пространственно-временных измерениях.

Конечно, априорная вероятность небольшой энтропии в момент $t_{0}$ очень низка. Но при условии, что энтропия, данная в момент $t_{0}$, является небольшой, какова вероятность, что существует термодинамическая стрела времени? Она, конечно, очень высока. Однако, полагая, что энтропия в $t_{0}$ низка, самый вероятный выбор состоит в том, что энтропия увеличивается в обоих направлениях с минимумом в $t_{0}$. (Мы представляем пример на Рис. 4 Разлела 0.4.4.) Ясно, в таком случае система является симметричной при инверсии $\left(t-t_{0}\right) \rightarrow-\left(t-t_{0}\right)$. Термодинамическая стрела времени для $t>t_{0}$ имеет противоположное направление, чем для $t<t_{0}$. Таким образом, даже при том, что никакое направление времени не является привилегированным глобально, термодинамическая стрела времени может, тем не менее, задаваться в местном масштабе для различных моментов времени $t \neq t_{0}$.

С другой стороны, в те моменты времени, на которых мы делаем измерение на практике, энтропия действительно низка, но энтропия не увеличивается в обоих направлениях. Вместо этого, это она увеличивается в только одном направлении. (Другими словами, типичное время $t_{0}$, в которое мы делаем измерение - это не момент времени, в которое энтропия достигает минимума. Это является причиной, что мы не наблюдаем временню симметрию) Для типичного момента $t_{0}$, не только "начальная"энтропия определена, но и специфическоенаправление увеличения энтропии определено также. На микроскопическом уровне, это связано с фактом, что в момент $t_{0}$ мы должен определить не только начальные положения частиц, но также и их начальные скорости.

А теперь центральный вопрос этого раздела. Учитывая, что в момент времени $t_{0}$ энтропия низка, почему энтропия в увеличивается в этот момент $t_{0}$ в одном и том же направлении (принимаемом за положительное) повсюду? Казалось бы, более вероятно, что направление увеличения энтропии изменяется от точки в момент $t_{0}$ ? Если так, тогда почему мы не наблюдаем это? Другими словами, почему стрела времени универсальна, имея одно и том же направление повсюду для данного момента $t_{0}$ ? Мы назовём эту проблему проблемой универсальности стрелы времени.

В этой статье мы утверждаем, что эта задача может быть решена статистической физикой. Короче говоря, наше решение следующие. Если мы игнорируем взаимодействия между различными подсистемами, то, при условии, что в $t_{0}$ энтропия низка, то самый вероятный выбор, действительно, что направление стрелы времени изменяется от точки к точке. С другой стороны, если 
различные подсистемы взаимодействуют друг с другом, то это больше не самый вероятный выбор. Вместо этого, даже если направление стрелки времени изменяется от точки к точке в момент $t_{0}$, то взаимодействие обеспечивает естественный механизм, который выравнивает все стрелы времени в одном и том же направлении.

Чтобы проиллюстрировать парадокс стрелы времени, часто используются мысленные эксперименты Лошмидта (парадокс обращения времени) и Пуанкаpe (теорема о возвратах). Соответствующие парадоксы в классической механике решены следующим образом. Классическая механика позволяет, по крайней мере в принципе, исключить любой эффект влияния наблюдателя на наблюдаемую систему. Однако, большинство реальных систем являются хаотическими. Таким образом, даже слабое возмущение может привести к экспоненциальному расхождению траекторий. Кроме того, существует незначительное взаимодействие между наблюдателем и наблюдаемой системой. Как простой пример, рассмотрим газ, расширяющийся из небольшой области пространства в большой объем. В этом процессе, идущем с увеличением энтропии, изменение во времени макроскопических параметров устойчиво по отношению к небольшим внешним возмущениям. С другой стороны, если все скорости будут обращены, то газ сожмется в начальный небольшой объем, но только в отсутствие любых возмущений. Этот процесс с уменьшением энтропии очевидно неустойчив, и небольшое внешнее возмущение преобразовало его в процесс с ростом энтропии. Таким образом, процессы с увеличением энтропии, устойчивы, а с уменьшением - нет. Естественное следствие этого - то, что направление стрелы времени (которое определено ростом энтропии) как наблюдателя, так и наблюдаемой системы выравнивается к одному и тому же направлению, из-за неизбежного незначительного взаимодействия между ними. Они могут возвратиться назад к начальному состоянию как в парадоксе Лошмидта, так и в парадоксе Пуанкаре только вместе (как система в целом). Таким образом, память наблюдателя оказывается стертой в конце, потому что мы предполагаем, что все, включая мозг наблюдателя, полностью вернулось к состоянию, идентичному прежнему состоянию, описывающему систему прежде, чем память была создана.. В процессе этого возврата стрелы времени как наблюдателя, так и наблюдаемой системы указывают в направлении обратном первоначальному. Отсюда можно вывести два следствия. Во-первых, рост энтропии наблюдается как в целой системе, так и в ее двух частях относительно собственной стрелы времени наблюдателя, несмотря на то, что энтропия уменьшается в координатном времени. Во-вторых, память наблюдателя стерта не только в самом конце, но также уже и близко к конечной точке, потому что наблюдатель не помнит своего "прошлого"(определенного относительно координатного времени), но помнит своё "будущее". Конечно, сам наблюдатель не может знать, что стрела времени полностью изменила ее направление, потому что он может только наблюдать физическое "прошлое"и "будущее"определенное не относительно координатного времени, а относительно направления, в котором энтропия увеличивается.

Действительно, может казаться весьма вероятным, что взаимодействие выровняет все стрелы времени в одном и том же направлении. Но тут возникает вопрос, - в каком именно направлении из двух возможных? Как может какое-нибудь одно направление быть предпочтительным, когда оба направления априорно одинаково вероятны? Общее направление выбирается случайно или оно может быть эффективно предсказано? Если есть две подсистемы с противоположными направлениями времени в $t_{0}$, то совместная система выберет направление "более сильной"подсистемы как их общее направление. Но какая 
подсистема будет "более сильная"? Та ли, что обладает большим числом степеней свободы? Или она выбирается по иному принципу?

На самом деле, "более сильная"стрела времени - это та, которая сонаправлена с координатным направлением времени. Действительно, ситуация тут не симметричная. Для $t<t_{0}$ (когда стрелы времени противонаправлены) взаимодействие отсутствует, а для $t>t_{0}$ оно появляется. Это асимметрия взаимодействия и определяет наблюдаемую асимметрию времени.

Обратим внимание также, что механизм, изложенный выше, не зависит значительно от относительных размеров этих двух подсистем. В частности если они имеют равный размер, то есть, для одной половины системы стрела времени ориентирована противоположно другой половине для $t_{0}<t \leq t_{1}$, общая стрелка времени для $t>t_{1}$ будет все еще определяться вышеупомянутой асимметрией в знании.

Далее обратим внимание, что качественные вероятностные аргументы, изложенные выше, верны для большинства систем, но не обязательно для всех возможных системах. Действительно, есть интересные физические системы, типа спин-эхо, в которых подсистема может иметь стрелу времени противоположную стреле времени окружающей ее среды. Дело в том, что такие системы исключения, а не правило. Таким образом, наши качественные вероятностные аргументы, несмотря на наличие таких систем все еще верны, при условии, что они не рассматриваются как строгие законы без исключений.

Фактически, не трудно понять качественно, почему исключения типа спинэха существуют. Во-первых, это система с относительно небольшим количеством степеней свободы, что делает статистические аргументы менее точными и флюктуации более вероятны в таких случаях. Во- вторых, взаимодействие этой системы с окружающей средой настолько слабо, что механизм выравнивания направления роста энтропии берет больше времени, чем в большинстве других систем. Действительно, даже система спин-эха, в конечном счете, после достаточного времени, выравнивает направление стрелы времени с ее окружающей средой.

Поскольку никакое направление времени не является априорно привилегированным, позвольте нам также кратко обсудить ситуацию, инверсную к вышеупомянутой. Для этой цели, теперь позвольте нам предположить, что взаимодействие существует только для $t<t_{-1}$, где $t_{-1}<t_{0}$. С помощью полностью аналогичных рассуждений, теперь мы можем заключить, что энтропия увеличится в отрицательный направление времени для $t<t_{-1}$.

Полностью симметрический вариант также возможен. Положим, что взаимодействие существует и для $t>t_{1}$, и для $t<t_{-1}$ (но не для $t_{-1} \leq t \leq t_{1}$ ). В этом случае, энтропия увеличивается в положительным направлении времени для $t>t_{1}$ и в отрицательном направлении времени для $t<t_{-1}$. Другими словами, подобно к случаю на Рис. 4] Раздела 0.4.4, энтропия увеличится в обоих направлениях, но в различные моменты времени.

Одно дополнительное примечание относительно начальных условий. Даже когда две подсистемы имеют противоположные направления термодинамической стрели времени, мы выбираем начальные условия для них обоих в один тот же момент времени $t_{0}$, скажем в прошлом. Действительно, выбор, для которого $t_{0}$ находится в прошлом - естественный выбор для подсистемы, в которой энтропия увеличивается со временем. Однако, этот выбор не настолько естественен для другой подсистемы, в которой энтропия уменьшается со временем. Для такой подсистемы было бы более естественно выбрать "начальное"условие в будущем. Или более широко, можно было бы изучить много подсистем, каж- 
дую с начальными условиями в разнментые моменты времени. Подчеркнем, что в этой статье мы не изучаем такие более общие начальные условия, потому что, когда взаимодействия между подсистемами существует, начальные условия, выбранные в разные моменты времни для разных подсистем, не могут быть заданы произвольно. А именно, для таких начальных условий, заданных в разные моменты времени, последовательное решение динамических уравнений движения не может даже существовать. И даже когда такое решение существует, не известно, как доказать его существование или как найти это решение в численной форме.

Теперь мы можем понять, почему стрела времени универсальна. Пусть есть подсистема, у которой есть стрела времени направленная противоположно нашей общей стреле времени, и эта подсистема или наблюдается, или не наблюдается нами. Если она не наблюдается, то это не нарушает того факта, что наша стрела времени кажется универсальной нам. Если она наблюдается, тогда она взаимодействует с нами. А это взаимодействие приводит к тому, что эти стрелы времени не могут быть противоположными в течение долгого времени. В любом случае - то, что мы наблюдаем, должно иметь то же самое направление времени (, что и наше (кроме, возможно, очень короткого временного интервала). Это подобно рассуждению в [6], с той важной разностью, что наше рассуждение не базируется на квантовой механике.

В остающихся разделах мы подтверждаем эти интуитивные идеи более количественным анализом.

\section{3 Статистическая физика Преобразования Пекаря}

Преобразования Пекаря (для более детального анализа смотри Приложение .1) отображает любую точку единичного квадрата на другую точку того же самого квадрата. Мы изучаем набор $N>>1$ таких точек (называемых "частицами"), который движется под воздействием Преобразования Пекаря. Это является "игрушечной"моделью для "газа который обладает всеми типичными свойствами классических Гамильтоновых обратимых детерминированных хаотических систем. Действительно, из-за его простоты, Преобразования Пекаря широко используется в таких целях [22 25].

\subsection{1 Макроскопическая энтропия и энтропия ансамбля}

Чтобы определить удобный набор макроскопических переменных, мы делим единичный квадрат на 4-ре равных подквадрата. Пусть 4-ре переменных $N_{1}$, $N_{2}, N_{3}, N_{4}$, обозначают число "частиц"в соответствующих подквадратах. Они и являются макроскопическими переменными для нашей системы. (Есть, конечно, много других удобных способов определить макроскопические переменные, но общие статистические закономерности не должны зависеть от этого выбора). Макроскопическая энтропия $S_{\mathrm{m}}$ данного макросостояния определяется числом различных микросостояний, соответствующих этому макросостоянию, и описывается следующей формулой

$$
S_{\mathrm{m}}=-N \sum_{k=1}^{4} \frac{N_{k}}{N} \log \left(\frac{N_{k}}{N}\right)=-\sum_{k=1}^{4} N_{k} \log \left(\frac{N_{k}}{N}\right) .
$$

Эта энтропия максимальна, когда распределение частиц равномерно, когда $S_{\mathrm{m}}$ равна $S_{\mathrm{m}}^{\max }=N \log 4$. В то время энтропия минимальна, когда все частицы 
находятся в одном подквадрате, т.е. когда $S_{\mathrm{m}}=0$.

Пусть $(x, y)$ dобозначают координаты точки на единичном квадрате. На физическом языке это соответствует положению частицы в 2-мерном фазовом пространстве. Для $N$ частиц мы рассматриваем статистический ансамбль с плотностью вероятности $\rho\left(x_{1}, y_{1} ; \ldots ; x_{N}, y_{N} ; t\right)$ на $2 N$ размерное фазовое пространство. Здесь $t$ i- временной параметр, который имеет дискретные значения $t=0,1,2, \ldots$ fдля Преобразования Пекаря. Тогда энтропия ансамбля определяется как

$$
S_{\mathrm{e}}=-\int \rho\left(x_{1}, y_{1} ; \ldots ; x_{N}, y_{N} ; t\right) \log \rho\left(x_{1}, y_{1} ; \ldots ; x_{N}, y_{N} ; t\right) d X
$$

где

$$
d X \equiv d x_{1} d y_{1} \cdots d x_{N} d y_{N}
$$

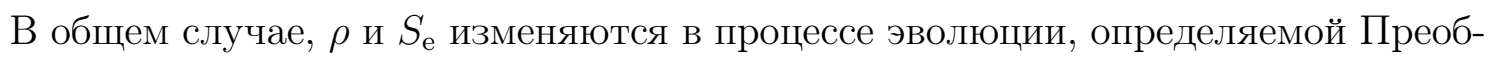
разованием Пекаря, и зависят от начальной $\rho$. Однако, если начальная функция плотности вероятности имеет форму

$$
\rho\left(x_{1}, y_{1} ; \ldots ; x_{N}, y_{N}\right)=\rho\left(x_{1}, y_{1}\right) \cdots \rho\left(x_{N}, y_{N}\right),
$$

которая соответствует некоррелированной функции плотности, тогда функция плотности вероятности остается некоррелированной в процессе дальнейшей эволюции.

Так, например, рассмотрим функцию $\rho\left(x_{l}, y_{l}\right)$, которая равномерна в пределах некоторой подобласти $\Sigma$ (с площадью $A<1$ ) единичного квадрата, и обращается в нуль за пределами $\Sigma$. Другими словами, пусть

$$
\rho\left(x_{l}, y_{l}, t\right)=\left\{\begin{array}{l}
1 / A \text { for }\left(x_{l}, y_{l}\right) \text { inside } \Sigma \\
0 \text { for }\left(x_{l}, y_{l}\right) \text { outside } \Sigma
\end{array}\right.
$$

В этом случае

$$
S_{\mathrm{e}}=-\left(\frac{1}{A}\right)^{N} \log \left(\frac{1}{A}\right)^{N} A^{N}=N \log A .
$$

Так как $A \mathrm{dA}$ не изменяется в процессе эволюции, определяемой Преобразованием Пекаря, то и $S_{\mathrm{e}}$ является постоянной в процессе эволюции, определяемой Преобразованием Пекаря. Этот пример иллюстрирует, что $S_{\text {е }}$ является фактически постоянной для произвольной начальной функции. Для доказательства, позвольте нам разделить единичный $2 N$-мерный ящик на большое количество небольших областей $\Sigma_{a}$, для каждой из которых вероятность равна $\rho_{a}$ В процессе эволюции каждая область $\Sigma_{a}$ изменяет форму, но ее $2 N$-мерная "площадь" $A_{a}$ остается неизменной. Кроме того, вероятность $\rho_{a}$ на новой области $\Sigma_{a}$ также остается неизменной. Следовательно, энтропия ансамбля $S_{\mathrm{e}}=-\sum_{a} A_{a}^{N} \rho_{a} \log \rho_{a}$ остается неизменной также. Это - основная идея дискретной версии доказательства, но и непрерывная версия может быть сделана подобным же способом.

\subsection{2 Соответствующие и несоответствующие макроскопические пе- ременные}

Макроскопические переменные, определенные в предыдущем подразделе имеют следующие свойства:

1. Для большинства начальных микросостояний, имеющих свойство $S_{\mathrm{m}}<$ $S_{\mathrm{m}}^{\max }, S_{\mathrm{m}}$ увеличивается под действием Преобразования Пекаря. 
2. Для большинства начальных микросостояний, имеющих свойство $S_{\mathrm{m}}=$ $S_{\mathrm{m}}^{\max }, S_{\mathrm{m}}$ остается постоянной под действием Преобразования Пекаря.

3. Два, описанных ыше свойства остаются в силе, когда Преобразования Пекаря дополнено небольшим шумом.

Назовем макропеременные, имеющие эти свойства, подходящими макропеременными. (Они являются "подходящими"в смысле, что соответствующий макроскопический закон увеличения энтропии может быть получен только, когда макропеременные повинуются этим свойствам.)

Отнюдь не любой разумный выбор макропеременных является подходящим. Это можно проиллюстрировать примером. Разделим единичный квадрат на $2^{M}$ одинаковых вертикальных полос $(M \gg 1))$. Мы определяем новое множество макропеременных как номера частиц в каждой из этих полос. Подобно формуле (1), соответствующая макроскопическая энтропия

$$
S_{\mathrm{m}}=-\sum_{k=1}^{2^{M}} N_{k} \log \left(\frac{N_{k}}{N}\right),
$$

где $N_{k}$ - число частиц в полосе $k$. Выберем следующее начальное условие: газ равномерно распределен в нечетных вертикальных полосах, в то время как четные полосы пусты. Тогда для этого начального условия выполняется $S_{\mathrm{m}}<S_{\mathrm{m}}^{\max }$ . При этом, в течение долгого времени эволюции системы, осуществляемой в соответствии с Преобразованием Пекаря, $S_{\mathrm{m}}$ не увеличивается ни для какого начального микросостояния, соответствующего этому начальному макросостоянию . В течение этой эволюции число заполненных полос уменьшается, а и их толщина увеличивается, пока только одна толстая заполненная вертикальная полоса не остается. Только после того, как это произойдет, $S_{\mathrm{m}}$ начинает увеличиваться. Следует обратить внимание, что эволюция по направлению к единственной полосе может быть легко разрушена небольшим возмущением.

Таким образом, мы видим, что вертикальные полосы приводят к неподходящим макропеременным. В противоположность этому, горизонтальные полосы приводят к подходящим макропеременным. (Однако, макропеременные, использованные в (1), все же более сподходящие, потому что они приводят к намного более быстрому росту $S_{\mathrm{m}}$.) Эта асимметрия между вертикальными и горизонтальными полосами - следствие характерной асимметрии самого Преобразования Пекаря относительно вертикальной и горизонтальной координаты. Эта асимметрия подобна асимметрии между каноническими координатами и импульсами в Гамильтоне классической механики для многих реальных систем. А именно, для реальных систем гамильтоновы функции содержат только локальное взаимодействие между частицами, где локальность подразумевает близость по координате, а не по импульсу.

Наконец, обратим внимание, что эволюция макроскопических переменных $N_{k}(t), k=1,2,3,4$, , найходится усреднением по ансамблю следующим образом

$$
N_{k}(t)=\int N_{k}\left(x_{1}, y_{1} ; \ldots ; x_{N}, y_{N} ; t\right) \rho\left(x_{1}, y_{1} ; \ldots ; x_{N}, y_{N} ; t\right) d X
$$

\subsection{3 Огрубление}

Как мы уже сказали, энтропия ансамбля (в отличие от макроскопической энтропии) - всегда константа в течение эволюциии, определяемой Преобразованием 
Пекаря. Однако, хотелось бы иметь модифицированное определение энтропии ансамбля, при котором энтропия увеличивалась бы подобно к макроскопической энтропии. Такая модификация обеспечивается огрублением, которое может быть обеспечено введением огрубленной фазовой функции плотности вероятности.

$$
\begin{aligned}
\rho^{\mathrm{coar}}\left(x_{1}, y_{1} ; \ldots ; x_{N}, y_{N}\right)= & \int \Delta\left(x_{1}-x_{1}^{\prime}, y_{1}-y_{1}^{\prime} ; \ldots ; x_{N}-x_{N}^{\prime}, y_{N}-y_{N}^{\prime}\right) \\
& \times \rho\left(x_{1}^{\prime}, y_{1}^{\prime} ; \ldots ; x_{N}^{\prime}, y_{N}^{\prime}\right) d X^{\prime}
\end{aligned}
$$

где $\Delta$ отлична от нуля в некоторой области $X^{\prime}=0,0 ; \ldots ; 0,0$. Таким образом, огрубленная энтропия ансамбля

$$
S_{\mathrm{e}}^{\mathrm{coar}}=-\int \rho^{\mathrm{coar}}\left(x_{1}, y_{1} ; \ldots ; x_{N}, y_{N}\right) \log \rho^{\mathrm{coar}}\left(x_{1}, y_{1} ; \ldots ; x_{N}, y_{N}\right) d X
$$

Конечно, функция $\Delta$ может быть выбрана многими способами. Дадим теперь несколько примеров.

Первый пример - огрубление Больцмана , определяемое следующим образом

$$
\rho^{\mathrm{coar}}\left(x_{1}, y_{1} ; \ldots ; x_{N}, y_{N}\right)=\rho\left(x_{1}, y_{1}\right) \cdots \rho\left(x_{N}, y_{N}\right),
$$

где

$$
\rho\left(x_{1}, y_{1}\right)=\int \rho\left(x_{1}, y_{1} ; \ldots ; x_{N}, y_{N}\right) d x_{2} d y_{2} \cdots d x_{N} d y_{N},
$$

И аналогично для других $\rho\left(x_{l}, y_{l}\right)$.

Другой пример - изотропическое огрубление имеющее форму

$$
\begin{gathered}
\Delta\left(x_{1}-x_{1}^{\prime}, y_{1}-y_{1}^{\prime} ; \ldots ; x_{N}-x_{N}^{\prime}, y_{N}-y_{N}^{\prime}\right)= \\
\Delta\left(x_{1}-x_{1}^{\prime}\right) \Delta\left(y_{1}-y_{1}^{\prime}\right) \cdots \Delta\left(x_{N}-x_{N}^{\prime}\right) \Delta\left(y_{N}-y_{N}^{\prime}\right) .
\end{gathered}
$$

Еще один пример - огрубление Пригожина [22]

$$
\Delta\left(x_{1}-x_{1}^{\prime}, y_{1}-y_{1}^{\prime} ; \ldots ; x_{N}-x_{N}^{\prime}, y_{N}-y_{N}^{\prime}\right)=\Delta\left(y_{1}-y_{1}^{\prime}\right) \cdots \Delta\left(y_{N}-y_{N}^{\prime}\right),
$$

которое является анизотропным огрублением вдоль сжимыющего направления $y$.

Наконец, позвольте нам упоминать огрубление, основанное на разделении системы на две меньшие взаимодействующие подсистемы. Огрубленная энтропия ансамбля для полной системы определена как арифметическая сумма неогрубленных энтропий ансамбля этих его подсистем. Такая огрубленная энтропия игнорирует корреляции между подсистемами.

Все эти типы огрубление имеют следующее свойство: Если начальное микросостояние таково, что макроскопическая энтропия увеличивается, то огрубленная энтропия ансамбля также будет увеличиваться для этого начального микросостояния. При этом, огрубление Пригожина имеет следующие преимущества перед огрублением Больцмана и изотропным огрублением:

Во-первых, если взять распределение начальных микросостояний такое, что его макроскопическия энтропия уменьшается. Тогда энтропия соответствующего ансамбля, огрубленная по Пригожину не уменьшается. В то же время, энтропия ансамбля, огрубленная по Больцману или согласно изотропному огрублению, будет уменьшаться. 
Во вторых, предположим, что задано распределение начальных микросостояний такое, что его макроскопическая энтропия увеличивается. Теперь рассмотрим некоторое "заключительное"состояние (называемое далее исходный ансамбль) с большой макроскопической энтропией, близкой к максимальной. После достижения системой этого заключительного состояния, рассмотрим полученное из него новое инверсное состояние, имеющего обратную во времени эволюцию (Это достигается просто симметричным пребразованием относительно диагонали единичного квадрата с переменой местами координат х и у). Тогда энтропия ансамбля, полученного после такого "обращения"и огрубленная по Пригожину, скачком уменьшается (по отношению к огрубленной энтропии "необращенного"исходного ансамбля, из которого она получена этим "обращением"). В то же время, энтропия ансамбля, огрубленная по Больцману или изотропному огрублению, остаётся почти неизменной.

Таким образом, огрубление Пригожина обеспечивает, самое адекватное описание закона увеличения энтропии ансамбля без всяких дополнительных предположений. Так, например, чтобы получить тот же самый результат с огрублением Больцмана, необходимо было бы использовать дополнительное предположение, называемое "гипотезой молекулярного хаоса"заключающейся в замене $\rho\left(x_{1}, y_{1} ; x_{2}, y_{2}\right)$ на $\rho\left(x_{1}, y_{1}\right) \rho\left(x_{2}, y_{2}\right)$ в уравнении движения для $\rho(x, y, t)$.

\section{4 Эффект слабого взаимодействия}

\subsection{1 Малые внешние возмущения}

Рост энтропии ансамбля может быть достигнут даже без огрубления, путем введения небольшого внешного возмущения в Преобразование Пекаря. Возмущение должно быть достаточно небольшим, чтобы не уничтожить рост макроскопической энтропии, но в то же самое время, должно быть достаточно сильным, чтобы предотвратить обратные процессы и возвраты Пуанкаре. Для большинства таких возмущений качественные особенности эволюции не зависят существенно от детального вида возмущения.

Существуют два метода, которыми внешнее возмущение может быть введено. Один метод состоит в том, чтобы ввести небольшой внешний случайный шум. Макроскопические процессы с увеличением макроскопической энтропии устойчивы по отношению к такому шуму. Однако, площадь области определения функции фазовой плотности больше не является инвариантом по отношению к возмущенному Преобразованию Пекаря. Этим методом энтропия ансамбля может увеличиваться.

Другой метод состоит в том, чтобы ввести слабое взаимодействие с окружающей средой (которой может служить и "наблюдатель"). Снова, макроскопические процессы с увеличением макроскопической энтропии устойчивы, но площадь области определения функции фазовой плотности больше не является инвариантом по отношению к возмущенному Преобразованию Пекаря. Следовательно, энтропия ансамбля может увеличиваться. Однако, такая система больше не изолирована. Теперь она часть большей системы, разделенной на две подсистемы. Следовательно, как было уже объяснено в Разделе 0.3.3, огрубленная энтропия ансамбля для полной системы может быть определена как сумма неогрубленных энтропий множества его подсистем. В следующем подразделе мы изучим слабые взаимодействия с окружающей средой более подробно. 


\subsection{2 Слабое взаимодействие и дезорганизация состояния с проти- воположными стрелами времени подсистем}

Для дальнейшего необходимо выбрать некоторое определенное взаимодействие между двумя "газами". В отсутствии взаимодействия, каждый из них эволюционирует согласно Преобразованию Пекаря. Мы помещаем два единичных квадрата один над другим и определяем взаимодействие с максимальным расстоянием $\sigma$ таким образом, что, между двумя последовательными шагами Преобразования Пекаря, все самые близкие пары частиц (с расстоянием между частицами, меньшим чем $\sigma$ ) обмениваются местами. (Более детально, мы сначала находим пару самых близких частиц (с расстоянием между частицами, меньшим чем $\sigma$ ) и обмениваем их местами. После этого, мы находим вторую пару самых близких частиц (с расстоянием между частицами, меньшим чем $\sigma$ , и отличные от ранее уже найденных частиц) и обмениваем их местами также. Мы повторяем эту процедуру до тех пор, пока не исчерпываются все такие частицы.) Эти взаимодействия определяются только между частицами лежащими в различных подсистемах. Такое взаимодействие не затрагивает движение частиц, но вызывает перемешивание между двумя подсистемами. Обратим также внимание, что такое перемешивание не ведет к парадоксу Гиббса, так как мы рассматриваем эти два единичных квадрата как две различные подсистемы. Макроскопическая энтропия определена как сумма макроскопических энтропий этих двух подсистем.

Теперь позвольте нам рассматреть случай, в котором стрелы времени этих двух подсистем имеют одинаковое направление. Процессы, в которых макроскопические энтропии этих двух подсистем увеличивается, являются устойчивыми по отношению к взаимодействию. Таким образом, большинство низкоэнтропийных начальных условий ведет к росту макроскопической энтропии обеих подсистем, так же как полной системы.

Точно так же, если мы обращаем описанный выше процесс с увеличением макроскопической энтропии, мы получаем систему, в которой макроскопическая энтропия обеих подсистем, так же как полной системы уменьшается. В этом смысле, взаимодействие не разрушает симметрию между двумя направлениями времени.

Теперь позвольте нам рассмотреть самый интересный случай, в котором энтропия увеличивается в первой подсистеме и уменьшениях во второй. Начальное состояние первой подсистемы обладает низкой энтропией (например, все частицы находятся в некотором небольшом квадрате около точки $(0,0)$ единичного квадрата). Аналогично, вторая подсистема обладает низкой энтропией (например, все частицы находятся в некотором небольшом квадрате около точки $(1,1)$ единичного квадрата) в конечном состоянии.

Если бы не было никакого взаимодействия, то конечное состояние первой подсистемы было бы высоко-энтропийным состоянием, соответствующим почти равномерному распределению частиц. Аналогично, начальное состояние второй системы было бы высоко-энтропийным состоянием той же самой формы.

Однако описанные выше решения с двумя противоположными стрелами времени больше не будут решениями, когда взаимодействие присутствует. В большинстве случаев, взаимодействие смешивает частицы между подсистемами. Число решений со взаимодействием, которые имеют те же начально-конечные условия, описанные выше, является очень небольшим, фактически намного меньшим, чем число таких решений в отсутствии взаимодействия.

Позвольте сделать последнее утверждение более количественным. После нечет- 
ного числа обменов между подсистемами частица проходит к другой подсистеме. Аналогично, после четного числа таких обменов, она остается в той же самой подсистеме. Вероятности для этих двух событий равны $p=1 / 2$ и не зависят от других частиц, по крайней мере, приблизительно. Далее, мы можем утверждать, что смешивание между этими двумя подсистемами незначительно в начальных и конечных состояниях, поскольку энтропии этих двух подсистем совершенно различны. Мы хотим вычислить вероятность небольшого смешивания для конечного состояния, при условии, что смешивание является небольшим в начальном состоянии. Для определенности мы будем считать, что смешивание является небольшим, если число частиц $N_{t}$, перешедших из одной подсистему в другую, является или $N_{t}<N / 4$, или $N_{t}>3 N / 4$. (Вспомним , что обмен частицами - только эффект возмущений, таким образом перемешивание не может зависеть ни от какой другой переменной, кроме $N_{t}$. Факторы $1 / 4$ и 3/4, конечно, выбраны произвольно, но мы устанавливаем их так, чтобы получить некоторые конкретные результаты в простой итоговой форме. Качественные результаты, которые отсюда следуют, не зависят от этого конкретного выбора.)

Таким образом, вероятность дана совокупным биномиальным распределением $F\left(N_{t} ; N, 1 / 2\right)$, описываемым

$$
F(k ; n, p)=\sum_{i=0}^{\lfloor k\rfloor}\left(\begin{array}{c}
n \\
i
\end{array}\right) p^{i}(1-p)^{n-i}
$$

где $\lfloor k\rfloor$ является самым большим целым числом, меньше чем или равным $k$. Функция $F(k ; n, p)$, удовлетворяет неравенству

$$
F(k ; n, p) \leq \exp \left(-2 \frac{(n p-k)^{2}}{n}\right) .
$$

Состояние с противоположными стрелами времени подсистем не дезорганизовано, когда $N_{t}<N / 4$ or $N_{t}>3 N / 4$. Вероятность этого равна

$$
2 F(N / 4 ; N, 1 / 2) \leq 2 e^{-N / 8} .
$$

Ясно, что эта вероятность уменьшается по экспоненте с увеличением $N$. Это означает, что такая вероятность пренебрежимо мала для большого $N$. Следовательно, почти бесспорно можно утверждать, что процессы с противоположными стрелами времени будут дезорганизованы.

В описанной выше модели, мы нуждаемся в почти равном числе частиц в этих двух подсистемах, чтобы дезорганизовать состояния с противоположными стрелами времени. Это связанно с тем, что одна частица может влиять на движение только одной близкой частицы. Для более реалистических взаимодействий одна частица может влиять на движение большого количества соседних частиц, что означает, что даже очень небольшое количество частиц в одной системе может разрушить процессы с уменьшением энтропии для другой системы.

\subsection{3 Декорреляция в системе с взаимодействием}

Гамильтоновы системы описываются не только макросостояниями, но также и сложными нелинейными корреляциями между микросостояниями. Эти корреляции ответственны за обратимость. Взаимодействие между двумя подсистемами разрушает эти корреляции в подсистемах, но полная система остается 
обратимой, то есть, корреляции появляются в полной системе. Таким образом, декорреляция в подсистемах распространяет корреляции на полную систему. (Этот процесс - классический аналог декогеренции в квантовой механике).

Позвольте нам изложить эти качественные идеи в более количественной форме. Линейная корреляция (корреляция Пирсона) имеет поведение, очень подобное поведению нелинейных корреляций, описанного выше. Единственная разница в том, что эти линейные корреляции уменьшаются со временем. Взаимодействие, которое мы предложили, может быть аппроксимировано случайным шумом с амплитудой, соответствующей расстоянию взаимодействия между частицами.

Поэтому, мы ожидаем, что взаимодействие не только вызывает выравнивание стрел времени, но также ведет к затуханию корреляций, которое происходит даже более значительно, чем это без взаимодействия (Раздел [.1.5). Во время этого процесса эволюция подсистем становится необратимой, но полная система остается обратимой.

Мы можем количественно найти величину этого затухания корреляций, вычисляя корреляцию Пирсона для наших подсистем, описываемую

$$
r(m)=\frac{C(m)}{\sqrt{C(0)\left\langle C^{m}(0)\right\rangle}}
$$

где $\left.\left\langle C^{m}(0)\right\rangle\right)>$ - ожидаемая дисперсия случайной величины $x$, вычисленной после $m$ итераций отображения. Дисперсия $C^{m}(0)$ может быть вычислена как as

$$
C^{m}(0)=\sum_{j=0}^{2^{m}-1} \int_{j 2^{-m}}^{(j+1) 2^{-m}}\left(2^{m} x-j-\langle x\rangle+S\right)^{2} d x,
$$

где $S$ - случайное число, определенное как $S=\sum_{k=0}^{m-1} 2^{k} \zeta_{k}$. Здесь $\zeta_{k}$ - независимое и однородно распределенное случайное число с нулевым средним и дисперсией $\sigma^{2}$, которое моделирует влияние взаимодействий на эволюцию системы. После короткого вычисления мы получаем

$$
\left\langle C^{m}(0)\right\rangle=C(0)+\left\langle S^{2}\right\rangle=C(0)+\sum_{k, k^{\prime}=0}^{m-1} 2^{k+k^{\prime}}\left\langle\zeta_{k} \zeta_{k^{\prime}}\right\rangle .
$$

Используя следующее свойство независимых и однородно распределенных случайных величин $\left\langle\zeta_{k} \zeta_{k^{\prime}}\right\rangle=\delta_{k k^{\prime}} \sigma^{2}$, мы получаем

$$
\left\langle C^{m}(0)\right\rangle=C(0)+\frac{2^{2 m}-1}{3} \sigma^{2} .
$$

Ясно, что взаимодействие увеличит затухание как минимум линейных корреляций, потому что

$$
r(m)=\frac{2^{-m}}{\sqrt{1+4\left(2^{2 m}-1\right) \sigma^{2}}} .
$$

Однако для полной системы корреляция Пирсона $r(m)=2^{-m}$ остается той же самой. Так как $\left\langle S^{2}\right\rangle^{1 / 2}$ должен быть намного меньшим, чем размер системы (единичный квадрат), мы можем заключить, что наши предположения, приводящие к (22) , правильны только для $\left\langle S^{2}\right\rangle=\left[\left(2^{2 m}-1\right) / 3\right] \sigma^{2} \ll 1$ and $\sigma^{2} / 2^{-2 m} \ll 1$. 


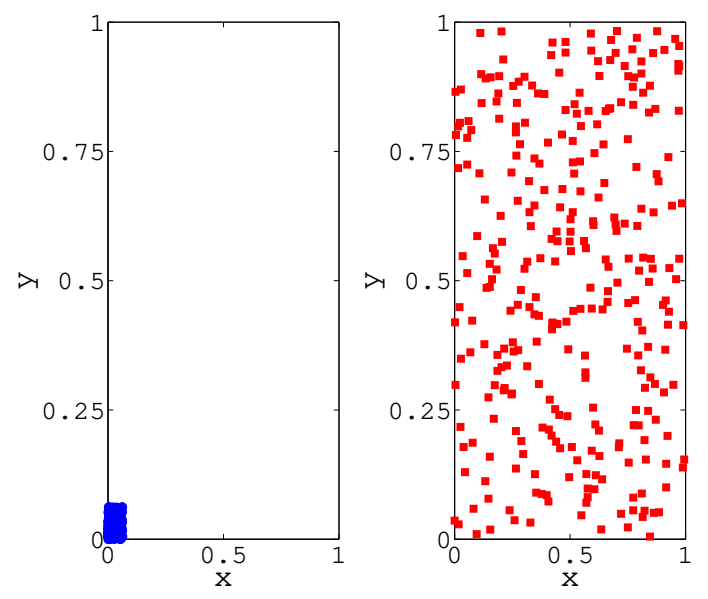

Рис. 1: Начальнаое распределение частиц в момент $t=1$.

\subsection{4 Численное моделирование}

Пока, мы использовали лишь общие абстрактные аргументы. В этом подразделе мы поддержим эти аргументы конкретным численным моделированием. Мы имеем две подсистемы (маркированные как 1 и 2), каждая с $N_{1}=N_{2}=$ 300 частиц. Эти две подсистемы занимают два единичных квадрата. Чтобы определить огрубленную энтропию, каждый единичный квадрат разделен на $16 \times 16=256$ небольших квадратов. Таким образом, энтропия каждой из этих двух подсистем даётся

$$
S_{i}=-N_{i} \sum_{k=1}^{512} f_{k, i} \log f_{k, i},
$$

где $i=1,2, f_{k, i}=n_{k, i} / N_{i}$ и $n_{k, i}$ являются числом частиц в соответствующих маленьких квадратах. Аналогично, полная энтропия определяется как

$$
S=-\left(N_{1}+N_{2}\right) \sum_{k=1}^{512} f_{k} \log f_{k},
$$

где $f_{k}=\left(n_{k, 1}+n_{k, 2}\right) /\left(N_{1}+N_{2}\right)$

Для системы 1 мы выбираем начальное состояние с нулевой энтропией в $t=$ 1 (см. Рис. 1). Точно так же, для системы 2 мы выбираем "конечное"состояние с нулевой энтропией в $t=6$.. Такие начальные условия обеспечивают, что в отсутствии взаимодействий $S_{1}$ іувеличивается со временем, в то время как $S_{2}$ уменьшается со временем для $t<6$.

Чтобы избежать численных проблем, являющихся результатом конечной точности компьютерного представления рациональных чисел, (27) заменено на $x^{\prime}=a x-\lfloor a x\rfloor, y^{\prime}=(y+\lfloor a x\rfloor) / 2$ с $a=1.999999$. Результаты численного моделирования представлены в Рис. 2 и Рис. 3 .

Чтобы включить эффекты взаимодействия, мы определяем взаимодействие следующим образом. (Ради вычислительного удобства это определено немного по-другому, чем в Разделе 0.4.2.) ). (Взаимодействие, используемое в разделе ?? выбрано так, чтобы сделать аналитические методы расчета более простыми, в то время как в существующей секции оно выбрано так, чтобы делать числовые вычисления более простыми.) Мы берем небольшой диапазон взаимодействия $r_{y}=0.01$ в $y$-направлении, который, по сути, является параметром, 


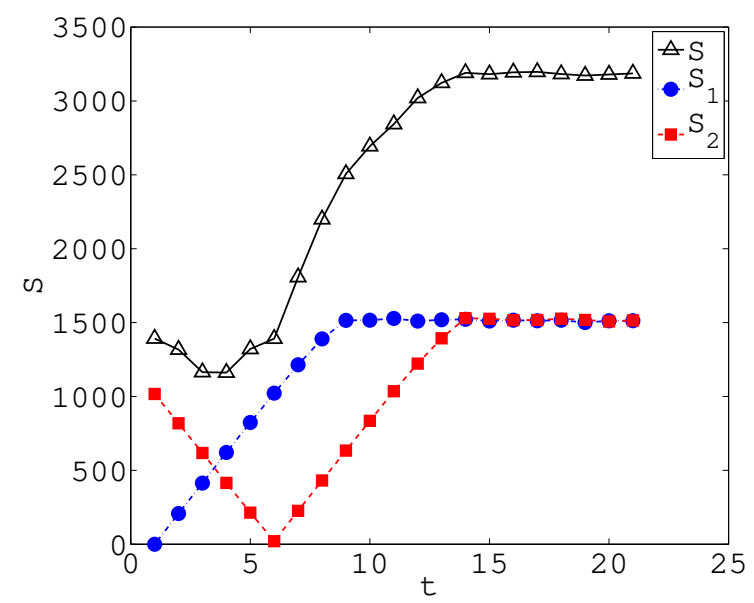

Рис. 2: Эволюция энтропии без взаимодействия.

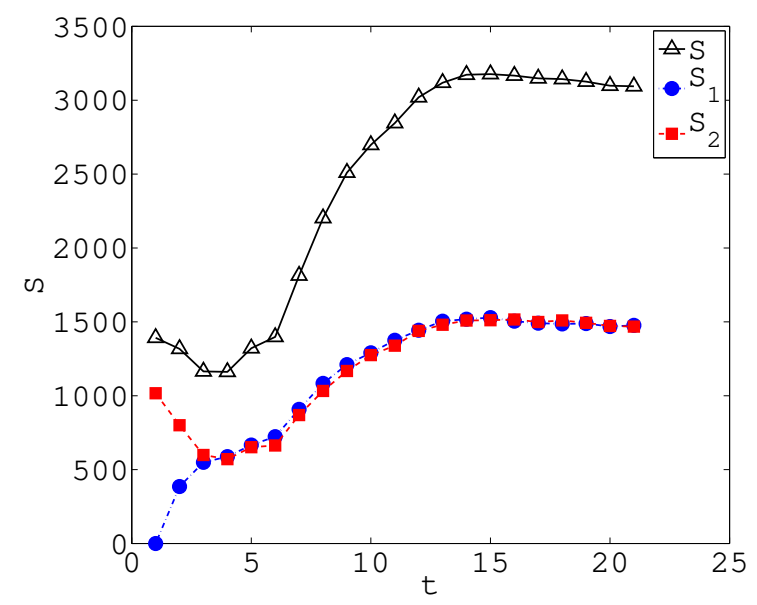

Рис. 3: Эволюция энтропии при взаимодействии.

описывающим слабость взаимодействия. (Вспомним, что $y$ и $x$ являются аналогами канонической координаты и канонического импульса, соответственно, в Гамильтоновом фазовом пространстве). Взаимодействие обменивает самые близкие пары так же как в Разделе 0.4.2, но теперь "самое близкое"относятся к расстоянию в $y$-направлении, и нет никакого обмена, если самое близкое расстояние больше чем $r_{y}$. Кроме того, теперь взаимодействие определено таким образом, что только $x$-координаты частиц обмениваются. Выбирая те же самые начальные условия в $t=1$ как в случае отсутствия взаимозависимости (Рис. 1), результаты численного моделирования с взаимодействием представлены на Рис. 3. Мы видим, что с взаимодействием (Рис. 3) $S_{2}$ S2 начинает увеличиваться в более раннее время, чем без взаимодействия (Рис. 22).

Наконец, мы даем пример симметричного развития времени при взаимодействии. Для этой цели, мы выбираем нулевую энтропию начального состояния в $t=0$ и для системы 1 и для системы 2. Два начальных распределения частиц (для двух подсистем) при нулевой энтропией различны. В частности они расположены в пределах двух различных маленьких квадратов, так что полная начальная энтропия больше, чем ноль. Результат числового моделирования представлен на Рис. 4. Мы видим, что решение является симметричным при инверсии времени $t \rightarrow-t$. 


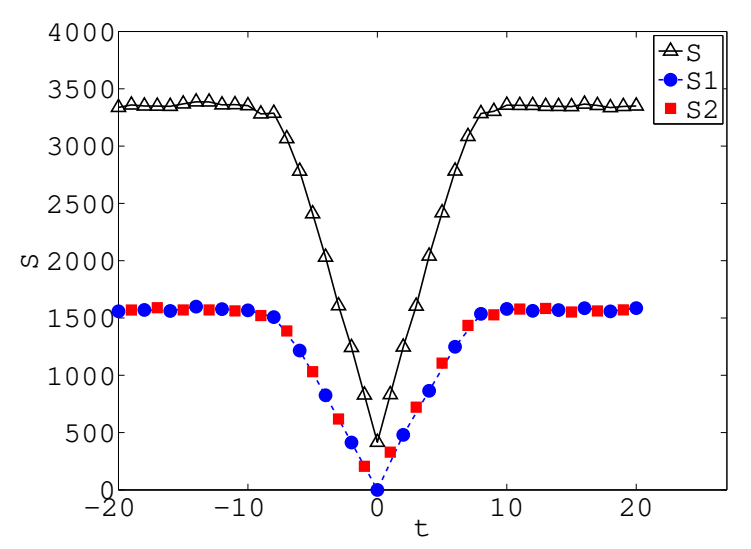

Рис. 4: Симметричная эволюция энтропии при взаимодействии.

\section{5 Выводы}

В этой статье мы использовали "игрушечную"модель, основанную на Преобразовании Пекаря, чтобы продемонстрировать особенности, которые, справедливы для общих систем, описанных обратимой Гамильтоновой механикой. Ясно, для таких систем можно свободно выбрать или конечные, или начальные условия, но нельзя свободно выбрать смешанные начально-конечных условия. Начально-конечных условия - это условия, при которых канонические параметры для одной части частиц определены в начальный момент времени, а для другой части - в конечный момент. Для многих смешанных начально-конечных условий не существует соответствующего решения (для Гамильтоновых уравнений движения). Точно так же, как для нашей "игрушечной модели для большинства Гамильтонианов со слабыми взаимодействием, число решений с данными крупнозернистыми начально-конечными условиями намного меньше, чем число решений с только крупнозернистыми начальными условиями, или только крупнозернистыми конечными условиями. Это объясняет, почему, практически, мы никогда не наблюдаем подсистемы с противоположными стрелами времени, то есть, почему стрела времени универсальна.

В некотором смысле, дезорганизация состояний с противоположными стрелами времени подобна эргодичности. Оба свойства справедливы во всех практических ситуациях, однако они не являются точными законами. Они верны для большинства реальных систем, но контр-примеры могут всегда быть найдены [26, 27]. Кроме того, оба свойства кажутся интуитивно очевидными, но доказать их строго очень трудно. Для эргодичности соответствующим строгим результатом является KAM (Колмогоров-Арнольд-Мозер) теорема, в то время как для дезорганизации состояний с противоположными стрелами времени такая строгая теорема отсутствует.

Наши результаты также разрешают "противоречие"между "Новой Динамикой"Пригожина [22] (обсужденной в Разделе 0.3 .3 из данной работы) и комментарием Bricmont [28]. Динамика взаимодействующих подсистем может быть разделена на два типа динамик:

1. Обратимую идеальную динамику, рассматриваемую относительно координатного времени, когда энтропия может или уменьшиться или увеличиться.

2. Необратимую наблюдаемую динамику, рассматриваемую относительно характерных стрел времени взаимодействующих подсистем, относительно 
которых энтропия может только увеличиваться, как уже показано выше.

В рамках этой терминологии "Новая Динамика"Пригожина 22] является одной из форм наблюдаемой динамики, в то время как статья Bricmont [28] рассматривает идеальную динамику. В частности, наблюдаемая динамика не включает возвращения Пуанкаре и обратимость, которые являются действительно ненаблюдаемыми реальным наблюдателем. Это делает её более простой, чем идеальная динамика. Однако, в принципе, оба типа динамики правильны.

Это рассуждение может также быть применено к интерпретации числовых результатов в Разделе. 0.4.4. Как Рис. 22, так и рис. 3 показывают, что стрела времени, определенная полной энтропией, полностью обращается в некоторый момент времени. Это обращение соответствует описанию идеальной динамикой. Но может ли быть наблюдаемо такое обращение? Ради концептуальной ясности мы подчеркиваем, что наблюдатель - только одна из подсистем, и разделяем вопрос на три различных. Первое, может ли наблюдатель наблюдать обращение своей собственный стрелы времени? Во- вторых, наблюдатель может наблюдать обращение стрелы времени его полного окружения? Третье, может ли наблюдатель наблюдать обращение стрелы времени малой части окружающей его среды?

Ответ на первый вопрос - нет, потому что наблюдатель естественным образом определяет стрелу времени как направление, в котором его собственная энтропия увеличивается. А именно, наблюдатель чувствует субъективный опыт потока времени, потому что каждый раз он имеет доступ к его памяти о некоторых событиях, которые не случаются прямо сейчас. Такие события естественно интерпретируются как его "прошлое". Можно утверждать, что память может работать, только когда энтропия увеличивается в направлении от запоминаемого случая до времени вспминания его (см., например, [20]). Точно так же другие процессы в мозгу (или компьютере) также, кажется, требуют увеличения энтропии для их нормального функционирования (см. также [3]). Таким образом, ожидается, что субъективный опыт наблюдателя о потоке времени всегда совпадает с направлением, в котором энтропия наблюдателя увеличивается.

Ответ на второй вопрос - почти наверняка нет, потому что, если полная окружение наблюдается, тогда оно взаимодействует с наблюдателем, и, следовательно, их стрелы времени имеют тенденцию быть сонаправлены, кроме, возможно, очень короткого времени, необходимого для процесса выравнивания направлений.

Ответ на третий вопрос иногда да, но обычно нет. А именно, некоторые специальные системы (например, спин-эхо, обсуждаемое в Разлеле. ??) может слабо взаимодействовать с их окружающей средой и все еще сохранить стрелу времени противонаправленной окружающей среде относительно долгое время. Такие специальные системы - относительно маленькие части полной окружающей среды, и наблюдатель может заметить, что такая подсистема имеет стрелу времени противоположную стреле времени этого наблюдателя. Действительно, поскольку мы уже объяснили в Разделе. 0.2, наши результаты, основанные на вероятностных рассуждениях для большинства система и не подразумевают, что абсолютно невозможно наблюдать подсистему, в которой энтропия уменьшается. Они только объясняют, почему такие системы, как ожидается, будут очень редкими, что соответствует нашему каждодневному опыту.

Тесно связанное с вышеизложенным наблюдение - это то, что наши результаты не находятся в противоречии с существованием диссипативных систем [29] (таких как, например, определенные самоорганизующиеся биологические системы), в котором энтропия подсистемы может уменьшиться со временем, несмот- 
ря на то, что энтропия окружающей среды увеличивается. Энтропия полной системы (включающей как энтропию диссипативной системы, так и окружающей среды) увеличивается, что отвечает закону увеличения энтропии. Для таких систем типично, что взаимодействие с окружающей средой сильно, в то время как результаты нашей статьи обращаются к слабым взаимодействиям между подсистемами. Например, для существования живых организмов, необходим большой поток энергии от Солнца. Небольшой поток энергии от звезд не достаточен для жизни, но достаточен для декорреляции и для выравнивания стрел времени. В работе [6]: приводится цитата: "Однако, наблюдатель является макроскопическим по определению, и все отдаленно взаимодействующие макроскопические системы становятся коррелированными очень быстро (например, Borel замечательно вычислил, что, перемещение одного грамма материала по звезде Сириус на один метр может влиять на траектории частиц в газе на Земле на временных масштабах порядка микросекунд [30])."

\section{Благодарности}

Мы благодарим анонимного рецензента за различные идеи, позволившие улучшить качество и ясность изложения. Работы H.N. и V.Z. были поддержаны Министерством Науки республики Хорватии согласно Контрактам Номер 0980982930-2864 и 098-0352828-2863, соответственно.

\section{Приложение}

\section{.1 Основные свойства Преобразования Пекаря}

В этом приложении мы представляем некоторые основные свойства Преобразования Пекаря. Больше деталей может быть найдено, например, в [31.

\section{.1 .1 Определение Преобразования Пекаря}

Рассмотрим бинарную символическую последовательность.

$$
\ldots S_{-2}, S_{-1}, S_{0} ; S_{1}, S_{2}, S_{3} \ldots
$$

бесконечную с обеих сторон. Такая последовательность определяет два вещественных числа

$$
x=0 . S_{1} S_{2} S_{3} \ldots, \quad y=0 . S_{0} S_{-1} S_{-2} \ldots
$$

Последовательность может быть перемещена обратимо относительно точки с запятой в обоих направлениях. После левого сдвига мы получаем новые действительные числа

$$
x^{\prime}=2 x-\lfloor 2 x\rfloor, \quad y^{\prime}=\frac{1}{2}(y+\lfloor 2 x\rfloor),
$$

где $\lfloor x\rfloor$ является самым большим целым числом, меньше чем или равным х. Это отображение единичного квадрата в себя называют Преобразованием Пекаря.

У Преобразования Пекаря есть есть простая геометрическая интерпретация, представленная в Рис. 5, Там (а) - начальная конфигурация, и (с) заключительная конфигурация после одной итерации Преобразования Пекаря, с промежуточным шагом, представленным в (b). Часть (d) представляет заключительную конфигурацию после двух итераций. 


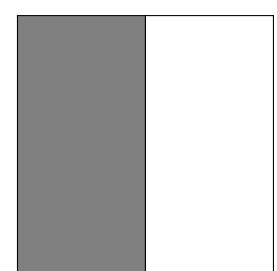

(a)

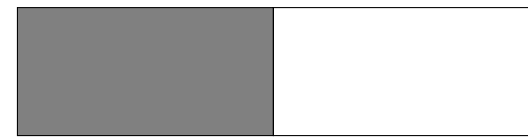

(b)

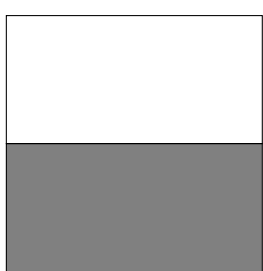

(c)

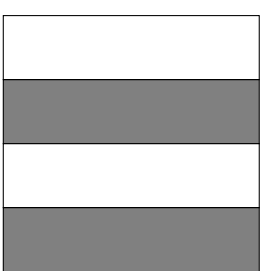

(d)

Рис. 5: Геометрическая интерпретация Преобразования Пекаря. (а) Начальная конфигурация (b) Однородное сжатие в вертикальном направлении и расширение в горизонтальном направлении на величину фактора 2 (с) Итоговая конфигурация после отрезания правой половины и её помещения на левую (d) Итоговое конфигурация после двух итераций.

\section{.1.2 Нестабильные периодические орбиты}

Периодические символические последовательности (0) и (1) соответствуют неподвижным точкам $(x, y)=(0,0)$ и $(x, y)=(1,1))$, соответственно. Периодическая последовательность (10) соответствует двухпериодичной орбите $\{(1 / 3,2 / 3),(2 / 3,1 / 3)\}$.

Из периодической последовательности ... 001; 001 . . мы получаем $\{(1 / 7,4 / 7),(2 / 7,2 / 7),(4 / 7,1 / 7)\}$. Точно так же из ...011; $011 \ldots$ мы получаем $\{(3 / 7,6 / 7),(6 / 7,3 / 7),(5 / 7,5 / 7)\}$.

Любой $x$ и $y$ могут быть аппроксимированы произвольно хорошо $0 . X_{0} \ldots X_{n}$ и $0 . Y_{0} \ldots Y_{m}$, соответственно, при условии, что $n$ и $m$ являются достаточно большими. Поэтому периодическая последовательность $\left(Y_{m} \ldots Y_{0} X_{0} \ldots X_{n}\right)$, может приблизиться к любой точке единичного квадрата произвольно близко. Таким образом, множество всех периодических орбит даёт плотное множество на единичном квадрате.

\section{.1.3 Эргодичность, перемешивание, и сохранение площади}

Из-за растяжения в горизонтальном направлении, все близкие точки расходятся по экспоненте под действием итераций Преобразования Пекаря. При этих итерациях любая случайная символическая последовательность приближается произвольно близко к любой точке единичного квадрата. Вообще, такое эргодическое свойство может использоваться, чтобы заменить среднее по "времени" $\langle A\rangle$ средним по "ансамблю"

$$
\langle A\rangle=\sum_{n} A\left(x_{n}, y_{n}\right)=\int A(x, y) d \mu(x, y)=\int A(x, y) \rho(x, y) d x d y
$$

где $d \mu(x, y)$ является инвариантной мерой и $\rho(x, y)$ инвариантная плотность для Преобразования Пекаря. Для Преобразования Пекаря, $\rho(x, y)=1$.

Под действием итераций Преобразования Пекаря любая область отображается в ряд узких горизонтальных полос. В конечном счете, они заполняют равномерно весь единичный квадрат, что и соответствует перемешиванию. Точно так же обратные итерации отображают область в узкие вертикальные ленты, которая также соответствует перемешиванию.

Во время этих итераций не изменяется площадь область. Это свойство закон сохранения площади области для Преобразования Пекаря. 


\section{.1.4 Показатели степени Ляпунова, сжимающиеся и растягиваю-} щиеся направления

Если $x_{0}^{(1)}$ и $x_{0}^{(2)}$ имеют равные первые $k$ двоичные цифры, то для for $n<k$,

$$
x_{n}^{(2)}-x_{n}^{(1)}=2^{n}\left(x_{0}^{(2)}-x_{0}^{(1)}\right)=\left(x_{0}^{(2)}-x_{0}^{(1)}\right) e^{n \log 2},
$$

где $\Lambda=\log 2$ іявляется первым положительным показателем степени Ляпунова для Преобразования Пекаря. Следовательно, расстояние между двумя близкими орбитами увеличивается по экспоненте с увеличением $n$, и после $k$ іитерации становится порядка 1. Это свойство называют чувствительностью к начальным условиям. Из-за этого свойства, все периодические орбиты неустойчивы.

Так как площадь область сохраняется, растяжение в горизонтальном направлении, обсужденная выше, подразумевает, что некоторое направление сжатия также должно существовать. Действительно, эволюция в вертикальном направлении $y$ обратна эволюции в горизонтальном направлении. Если $\left(x_{0}^{(1)}, y_{0}^{(1)}\right)$ и $\left(x_{0}^{(2)}, y_{0}^{(2)}\right)$ являются двумя точками с $x_{0}^{(1)}=x_{0}^{(2)}$, тогда

$$
y_{n}^{(2)}-y_{n}^{(1)}=2^{-n}\left(y_{0}^{(2)}-y_{0}^{(1)}\right)=\left(y_{0}^{(2)}-y_{0}^{(1)}\right) e^{n(-\log 2)} .
$$

Следовательно, $\Lambda=-\log 22$ - это второй отрицательный показатель степени Ляпунова для Преобразования Пекаря.

\section{.1 .5 Затухание корреляций}

Так как $x$ - неустойчивое направление, эволюция в этом направлении приводит к затуханию корреляций. Средняя корреляционная функция $C(m)$ для последовательности $x_{k}$ обычно определяется как

$$
C(m)=\lim _{n \rightarrow \infty} \frac{1}{n} \sum_{k=1}^{n}\left(x_{k}-\langle x\rangle\right)\left(x_{k+m}-\langle x\rangle\right),
$$

где $\langle x\rangle=\lim _{n \rightarrow \infty} \sum_{k=1}^{n} x_{k} / n$. Корреляции могут быть более легко вычислены, если известна инвариантная мера $\mu(x)$, в этом случае

$$
C(m)=\int(x-\langle x\rangle)\left(f^{m}(x)-\langle x\rangle\right) d \mu(x),
$$

где $f^{m}(x)=x_{m}$ - функция, которая отображает переменную $x$ на ее образ после $m$ итераций Преобразования Пекаря. Для Преобразования Пекаря $d \mu(x)=d x$, таким образом, мы можем написать

$$
C(m)=\sum_{j=0}^{2^{m}-1} \int_{j 2^{-m}}^{(j+1) 2^{-m}}(x-\langle x\rangle)\left(2^{m} x-j-\langle x\rangle\right) d x
$$

который приводит к

$$
C(m)=\sum_{j=0}^{2^{m}-1}\left[2^{m} \frac{x^{3}}{3}-\left(2^{m}\langle x\rangle+\langle x\rangle\right) \frac{x^{2}}{2}+\langle x\rangle^{2} x-j\left(\frac{x^{2}}{2}-\langle x\rangle x\right)\right]_{j 2^{-m}}^{(j+1) 2^{-m}} .
$$

Для Преобразования Пекаря $\langle x\rangle=1 / 2$, и, таким образом, написанная выше сумма может быть вычислена явно

$$
C(m)=\frac{2^{-m}}{12}
$$


Это показывает, что затухание корреляций происходит по экспоненте с увеличением m. Корреляция Пирсона для системы находится следующим образом

$$
r(m)=C(m) / C(0)=2^{-m} .
$$




\section{Литература}

[1] H. Reichenbach, The Direction of Time (University of California Press, Los Angeles, 1971).

[2] P.C.W. Davies, The Physics of Time Asymmetry (Surrey University Press, London, 1974).

[3] R. Penrose, The Emperor's New Mind (Oxford University Press, 1989).

[4] H. Price, Time's Arrow and Archimedes' Point (Oxford University Press, New York, 1996).

[5] H.D. Zeh, The Physical Basis of the Direction of Time (Springer, Heidelberg, 2007).

[6] L. Maccone, Phys. Rev. Lett. 103, 080401 (2009).

[7] L. Vaidman, quant-ph/9609006.

[8] O. Kupervasser, nlin/0407033.

[9] O. Kupervasser, nlin/0508025.

[10] D. Jennings, T. Rudolph, Phys. Rev. Lett. 104, 148901 (2010).

[11] O. Kupervasser, D. Laikov, arXiv:0911.2610.

[12] H. Nikolić, arXiv:0912.1947.

[13] L. Maccone, arXiv:0912.5394.

[14] H.D. Zeh, Entropy 7, 199 (2005).

[15] H.D. Zeh, Entropy 8, 44 (2006).

[16] O. Kupervasser, arXiv:0911.2076.

[17] W. Thomson, Proc. Roy. Soc. Edinburgh 8, 325 (1874); reprinted in S.G. Brush, Kinetic Theory (Pergamon, Oxford, 1966).

[18] J.L. Lebowitz, Turkish Journal of Physics 19, 1 (1995); cond-mat/9605183.

[19] G.F.R. Ellis, Gen. Rel. Grav. 38, 1797 (2006).

[20] H. Nikolić, Found. Phys. Lett. 19, 259 (2006).

[21] H. Nikolić, http://www.fqxi.org/data/essay-contestfiles/Nikolic_FQXi_time.pdf. 
[22] I. Prigogine, From Being to Becoming (W.H. Freeman and Company, New York, 1980)

[23] Y. Elskens, R. Kapral, J. Stat. Phys. 38, 1027 (1985).

[24] P. Gaspard, J. Stat. Phys. 68, 673 (1992).

[25] G.C. Hartmann, G. Radons, H.H. Diebner, O.E. Rossler, Discrete Dynamics in Nature and Society 5, 107 (2000).

[26] L.S. Schulman, Phys. Rev. Lett. 83, 5419 (1999).

[27] L.S. Schulman, Entropy 7, 208 (2005).

[28] J. Bricmont, chao-dyn/9603009.

[29] I. Prigogine, Self-organization in nonequilibrium systems (John Wiley \& Sons, 1977).

[30] E. Borel, Le Hasard (Alcan, Paris, 1914).

[31] D.J. Driebe, Fully Chaotic Maps and Broken Time Symmetry (Kluwer Academic Publishers, Dordrecht, 1999). 